University of Louisville

ThinkIR: The University of Louisville's Institutional Repository

Electronic Theses and Dissertations

$5-2007$

\title{
Viewed through new lenses : a comparative study of young girls growing up in Madison, Indiana, and Louisville, Kentucky, during World War II.
}

Michella M. Marino 1982-

University of Louisville

Follow this and additional works at: https://ir.library.louisville.edu/etd

\section{Recommended Citation}

Marino, Michella M. 1982-, "Viewed through new lenses : a comparative study of young girls growing up in Madison, Indiana, and Louisville, Kentucky, during World War II." (2007). Electronic Theses and Dissertations. Paper 906.

https://doi.org/10.18297/etd/906

This Master's Thesis is brought to you for free and open access by ThinkIR: The University of Louisville's Institutional Repository. It has been accepted for inclusion in Electronic Theses and Dissertations by an authorized administrator of ThinkIR: The University of Louisville's Institutional Repository. This title appears here courtesy of the author, who has retained all other copyrights. For more information, please contact thinkir@louisville.edu. 
VIEWED THROUGH NEW LENSES: A COMPARATIVE STUDY OF YOUNG GIRLS GROWING UP IN MADISON, INDIANA, AND LOUISVILLE, KENTUCKY, DURING WORLD WAR II

\author{
By \\ Michella M. Marino \\ B.A., Hanover College, 2004
}

\begin{abstract}
A Thesis
Submitted to the Faculty of the

Graduate School of the University of Louisville in Partial Fulfillment of the Requirements

for the Degree of
\end{abstract}

Master of Arts

Department of History

University of Louisville

Louisville, Kentucky

May 2007 
VIEWED THROUGH NEW LENSES: A COMPARATIVE STUDY OF YOUNG GIRLS GROWING UP IN MADISON, INDIANA, AND LOUISVILLE, KENTUCKY, DURING WORLD WAR II

\author{
By \\ Michella M. Marino \\ B.A., Hanover College, 2004
}

A Thesis Approved on

April 12, 2007

by the following Thesis Committee:

Thesis Director 


\section{DEDICATION}

This thesis is dedicated to my husband

\section{Tony Marino}

whose constant love and support was invaluable in this process

as was the comfortable computer chair he bought for me

and to

Mary Jane Bear

who helped get this project underway and whose presence is dearly missed. 


\section{ACKNOWLEDGMENTS}

I would like to thank my thesis advisor and mentor, Dr. Tracy K'Meyer, for all the advice, help, and aid she provided me in this daunting process. She always pushed me to go a step further than I thought I could. I also would like to thank Dr. Ann Allen and Dr. John McLeod for the assistance they have provided me during my education at UofL and their belief in my capabilities, along with Dr. Cate Fosl for being on my thesis committee. The entire History Department and staff has gone above and beyond their duties to assist me in this process and many others, and I am grateful for their kindness. Much thanks goes out to George Kirk, who took the time to proofread this paper for the girl who gets him coffee. And of course, my eternal thanks go out to my family, in-laws, and friends, who always support me in all my endeavors. 


\begin{abstract}
VIEWED THROUGH NEW LENSES: A COMPARATIVE STUDY OF YOUNG GIRLS GROWING UP IN MADISON, INDIANA, AND LOUISVILLE, KENTUCKY, DURING WORLD WAR II
\end{abstract}

Michella M. Marino

April 12, 2007

This thesis presents the view of World War II, a watershed event in U.S. history, through the lenses of a group that is not normally called upon, that of young children. The war was viewed by and affected young girls differently than others. Granted, some aspects of the war affected all people in a similar fashion, regardless of age and gender. This study, however, focuses on girls born between the years of 1929 and 1936, with the goal of describing the experience of children in two communities by determining what factors do and do not affect that experience and thereby contributing to our knowledge of the war's impact in the Ohio River Valley.

Based on oral histories of three women who grew up in Louisville and three women who grew up in Madison during the war, supplemented by secondary literature on children and war along with local newspaper sources, it is apparent the changes World War II brought to the cities of Louisville, Kentucky, and Madison, Indiana, affected the lives of young girls growing up in both these areas similarly. The changes the war brought to the lives of the six girls did not vary greatly due to the size of their urban or rural city. Instead, the determining factors appear to be the girls' young age and middle 
to lower class status. Regardless of the size of their cities, the girls experienced whatever location they were in as a smaller community because their age and social status limited their mobility and childhood experiences. These factors, as opposed to size of location, caused these six girls to be similarly affected by WWII concerning industrial changes, childhood activities, and personal households. The WWII era stories of these girls thus suggest a potential pattern in how children experience major national events. 
TABLE OF CONTENTS

PAGE

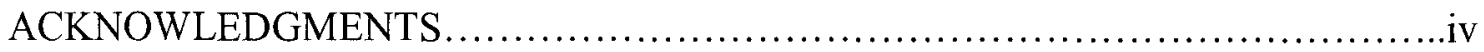

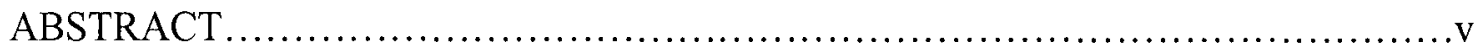

\section{CHAPTER}

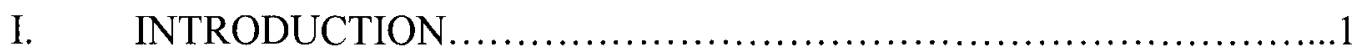

II. MADISON, INDIANA, AND LOUISVILLE, KENTUCKY, DURING THE WAR ......................................................15

III. WAR INDUSTRY AND SIZE ......................................56

IV. COMMUNITY, CHILDHOOD ACTIVITIES, PROPAGANDA, AND

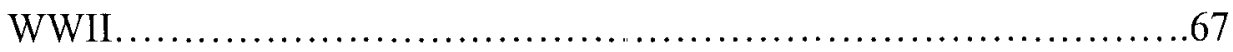

V. HOUSEHOLDS, PERSONAL LIVES, MEMORIES, AND WWII.........86

VI. CONCLUSION .................................................... 102

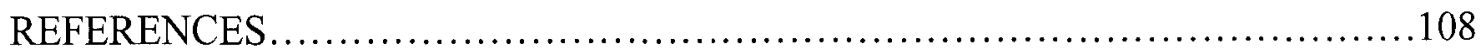

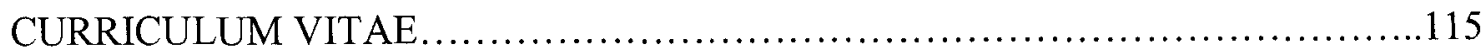




\section{CHAPTER I}

\section{INTRODUCTION}

The homefront experience of World War II has been studied in depth from almost every angle, ranging from the viewpoints of Rosie the Riveters, war brides, African Americans, Japanese Americans, and politicians, to name a few. Rarely though has the perspective of our nation's youngest citizens been studied. Young people who were raised during this time - the sons and daughters, and little brothers and sisters, of the 'greatest generation' - had both a distinct perspective on the war and set of experiences. Childrens' experiences of war and its impact on then has two broader implications. First, what happens to those children as they are growing up can certainly affect the future of that nation. Their opinions, beliefs, and experiences with such a watershed event as WWII can potentially affect their adult lives and therefore the decisions made in the future. Secondly, to tell the full history of any event, all angles and perspectives must be investigated. Thus, the homefront experience of WWII cannot fully be understood or completed without studying all of those involved in the event. While this may be an ongoing task that takes years or perhaps decades to accomplish, or may never be fully accomplished, examining the experiences of America's children on the homefront during WWII is a step towards this goal. 
Scholars in many disciplines and countries have studied children's experiences from the Revolution through the Civil War, World War II, and even the Cuban Missile Crisis. They have found that children shared certain similar wartime experiences and feelings but that factors such as age, gender, influence of media/propaganda, class, family structure, ethnicity, location, and culture prohibit all children from having a standard wartime experience. This study examines the experience of young girls in Madison, Indiana, and Louisville, Kentucky, and argues that while size of location in this casestudy does not matter, age and class do. Girls in both cities had similar experiences concerning wartime industry, childhood activities, propaganda and media, household changes, and memories. But their age and class restricted their mobility and circumscribed their lives in such a way as to produce a common small town experience regardless of location or size of community.

Childhood is a loose term that has not been easily or consistently understood over time by diverse groups. Even though childhood may be defined in a particular way by a certain people or government, in reality its meaning varies with regional and cultural values. The definition of childhood in the United States in the $20^{\text {th }}$ century was shaped by specific ideas held by government officials, parents, and medical and psychological specialists. Kriste Lindenmeyer's 2005 book The Greatest Generation Grows Up: American Childhood in the 1930s provides insight into the creation of the modern American childhood. Lindenmeyer criticizes historians who do not view "children and adolescents as active participants" in the Great Depression era, arguing instead that these children "both influenced and were targets of important social and political changes 
during the Great Depression years." It was during this era when "important shifts that embedded an ideal of modern American childhood in popular culture, law, and public policy" occurred. ${ }^{2}$ Childhood was legally defined in the 1930s for the first time by the federal government as a period of dependency from birth until the age of seventeen. According to Lindenmeyer, this new definition of childhood, along with the new role the government accepted through New Deal programs as "ultimate protector for America's children," was important because it "marked the shift from past ideas that had emphasized individualism over commonality in the lives of the nation's youngest citizens.” ${ }^{3}$ The new model of American childhood represented it as a stage of life devoid of adult responsibilities and emphasized schooling as opposed to working, raised age requirements for marrying, and placed restrictions on working habits and conditions. Lindenmeyer believes that these ideals existed since the previous century, but "it took the social and economic turmoil of the 1930s to stimulate the creation of a legal and cultural framework promoting the model as the normative experience for all Americans through age seventeen." ${ }^{4}$

Despite this general definition, Lindenmeyer and others note that certain factors hinder the development of a standard or normative childhood experience. First, childhood is more accurately broken into different ages, and the age at which a child experiences a particular event will greatly determine that experience. For the purpose of this study, war in particular affects children differently if they have reached the age of consciousness prior to, during, or after the war. In "Daddy's Gone to War": The Second

\footnotetext{
${ }^{1}$ Kriste Lindenmeyer, The Greatest Generation Grows Up: American Childhood in the 1930s, (Chicago: Ivan R. Dee, 2005), 3.

${ }^{2}$ Ibid.

${ }^{3}$ Ibid, 4 .

${ }^{4}$ Ibid, 5 .
} 
World War in the Lives of America's Children (1993), William M. Tuttle, Jr. focuses on two groups of children during WWII using Norman B. Ryder's definition of a cohort, which is "the aggregate of individuals (within the same population definition) who experienced the same event within the same time interval." Taking the cohort of children born between the years of 1932 and 1945, Tuttle describes "intragroup cohorts": children born between 1932 and 1935, those born between 1936 and 1941, and finally the "war babies," as those born between 1942 and the end of the war. Tuttle argues for this division noting the "vast differences in outlook that existed between the oldest members of this cohort and the youngest." 6 For instance, children in the first subcohort had already been affected economically and psychologically by the Depression and carried burdens with them due to these experiences. The second subcohort was affected by the Great Depression but was defined by war. Of course the final subcohort children begin their lives during the war, so it is all they know in their early years. Tuttle's smaller cohorts provide "an age-specific perspective [which] helps to sort out the history of children's wartime experiences," because children growing up in the WWII era had "vast differences in outlook" depending on their age. ${ }^{7}$

Published a year after Tuttle's book, Robert William Kirk's Earning Their Stripes: The Mobilization of American Children in the Second World War also focuses on a particular age group. Kirk's purpose is to "examine those experiences, lessons, and perceptions that made the World War II 6- to 13-year-old age cohort different from the deprived Depression-decade cohort which preceded them, and from the earth-shaking

\footnotetext{
${ }^{5}$ William M. Tuttle, Jr., "Daddy's Gone to War": The Second World War in the Lives of America's Children, (New York: Oxford University Press, 1993), 17.

${ }^{6}$ Ibid, 249.

${ }^{7}$ Ibid, quote on $17,249-252$.
} 
generation of protesters which followed." ${ }^{\prime 8}$ Although Kirk does not narrow his age groups as Tuttle does, he believes that this age cohort shared similar experiences during WWII, and "adults who were children on the homefront have vivid memories of how the war affected their childhoods and what they did to aid in the war effort. These memories help define their experiences." " For instance, these adults remember being mobilized to collect scrap materials, grow victory gardens, and knit for the troops, as well as the propaganda that reminded them that "Loose lips sink ships."10 Essentially, Tuttle and Kirk maintain that a child's age during wartime affects his/her experiences during war along with the memories that follow it. Therefore, the age a child is during war determines what experiences the child has.

Gender is a second factor that affects American children's wartime experiences. Tuttle and Kirk agree that gender influences the views, actions, reactions, and memories of war. While both Tuttle and Kirk focus particularly on the WWII era, the authors in Children and War: A Historical Anthology, edited by James Marten and published in 2002 , focus on children's memories of war and the meanings these memories have; the lessons and literature taken from war and created due to war; and children's behavior as both actors and victims of war, spanning across the globe and covering wars from the $18^{\text {th }}$ century to the present day. On the topic of gender specifically, Elizabeth McKee Williams demonstrates in "Childhood, Memory, and the American Revolution" how gender differences are apparent in the memoirs of children of the Revolutionary War. Gender skewed the type of narrative children relayed. For instance, young girls'

\footnotetext{
${ }^{8}$ Robert William Kirk, Earning Their Stripes: The Mobilization of American Children in the Second World War, (New York: Peter Lang, 1994), 2.

${ }^{9}$ Ibid , 3.

${ }^{10}$ Ibid.
} 
narratives focused more on the family and less on adventure, while boys talked about combat experience. Women who were girls during the war and were writing later for religious reasons said almost nothing about the war, while men writing for the same reasons "often spoke at length about the war, sometimes but not always stressing the moral threats which accompanied wartime violence." 11 Although referring to a much later war, i.e. WWII, Tuttle sums up the affects of gender by stating, "In ways both subtle and obvious, gender neatly divided the homefront children, and, in so doing, it provided boys with wartime experiences often substantively different from those which girls had."12

Tuttle, Kirk, and Marten all refer to children's war games to highlight gender differences. Williams's essay in Children and War shows how gender differences were revealed in war play as early as the Revolution. Many boys recalled martial play such as forming companies and practicing drills with wooden guns. They dressed the part and their parents cheered them on. Often boys did not consider this play but rather "preparation for joining the militia at age sixteen." "I In contrast, young girls "described play that was totally separate from war." ${ }^{14}$ Describing a later war, Kirk concurs with this, arguing that girls' "parts in war games were, on the whole, different from those of boys and their participation reinforced their ascribed gender roles." ${ }^{\prime 15}$ Despite changes in women's lives during the war, girls gender roles changed little. Kirk explains that "the wartime roles played by their mothers did little to instill a spirit of gender equality in

\footnotetext{
${ }^{11}$ Elizabeth McKee Williams, "Childhood, Memory, and the American Revolution," in Children and War: A Historical Anthology, ed. James Marten, With a Foreward by Robert Coles (New York: New York University Press, 2002), 22-23.

${ }^{12}$ Tuttle, 230.

${ }^{13}$ Williams, 23.

${ }^{14}$ Ibid.

${ }^{15}$ Kirk, 106.
} 
girls; while the war may have brought them out of the kitchen and into the factory, mothers by necessity assumed temporary and ancillary positions." itself was gender segregated until women's branches were added to the U.S. services. While at first girls were generally assigned to play nurses, over time they could mimic the WACs or WAVES, which put them temporarily on a "“more equal footing." "17 Despite this break into new games, for the most part the reality was that whether consciously or unconsciously, girls prepared and were prepared for their post-war roles as mothers and homemakers. $^{18}$

A third recurring factor influencing childhood experiences in wartime was the influence of media and propaganda, including the movies, radio, posters/billboards, newspapers, and comic books, to highlight a few. According to Lindenmeyer, as consumerism faltered during the Great Depression, advertisers, left with a shrinking market, turned some of their attention to children "who thus became more important as independent consumers." 19 These children were not only targeted as consumers but also as people to be influenced psychologically. During the Second World War, Kirk maintains media propaganda and the American government "led children to hate the enemy." ${ }^{20}$ Children during WWII were afraid of and despised Nazi brutality but also acquired a hatred for the Japanese due to their well-known brutality and on pure racial grounds alone. Therefore, "prejudice against Japanese became a defining aspect of that generation" even though some have managed to "[unlearn] it." ${ }^{, 21}$ On a more positive

\footnotetext{
${ }^{16}$ Kirk, 4.

${ }^{17} \mathrm{Ibid}, 23$.

${ }^{18} \mathrm{Ibid}, 107$.

${ }^{19}$ Lindenmeyer, 158.

${ }^{20}$ Kirk, 4.

${ }^{21} \mathrm{Ibid}$.
} 
level, Kirk believes that these same government and media influences made children more patriotic through their "intense propaganda and mobilization for unpaid war work." ${ }^{22}$ Homefront children were ingrained with a sense of strong patriotism through daily bombardment of messages from the media, the school, their peers, and their clubs. ${ }^{23}$

The forms of media that children were exposed to and the messages the media sent out affected the way the children viewed the war and the experiences they had during that war. Children who were taught to hate the enemy or a certain racial group potentially carried that hate with them the rest of their lives. Children ingrained with patriotism also carried that loyalty to their country with them. Many wartime parents, at least during WWII, believed that "children's sense of morality would be debased through unwholesome media messages." ${ }^{24}$ Despite the messages' level of wholesomeness, they influenced young minds, sometimes permanently and sometimes temporarily, and shaped the children's wartime experiences.

Age, gender, and media/propaganda consistently reappear as influencing factors in scholarly work on children and wartime, particularly concerning WWII. All three factors affect children's experiences during war in a manner that prevents a universal experience of wartime. Although these factors have attracted the attention of most scholars, others can influence children's wartime experiences, such as location or size of community. Marten, Tuttle, Lindenmeyer, and Kirk agree that these factors are important, but none discuss it at length. Kirk's work is limited in scope and does not examine geography. Tuttle devotes a few pages to regional differences but focuses within those pages on how regional culture and tradition affected child rearing and family

\footnotetext{
${ }^{22}$ Kirk, 4.

${ }^{23} \mathrm{Ibid}$.

${ }^{24} \mathrm{Ibid}, 34$
} 
life. He specifically mentions urban and rural differences but does not spend a significant amount of time explaining how these differences affect the children's experiences themselves. Some work has been done on region and location during the war, particularly concerning urban and rural differences. Pre-school teacher Claudia Lewis did a study on children during WWII in New York City in comparison to those growing up in eastern Tennessee, with a focus on the "childhood circumstances as well as the child-rearing traditions of these two societies. ${ }^{, 25}$ The profound differences she discovered were surprising because they "existed in a nation whose population-with the monumental exception of people of color-was reportedly being rapidly assimilated in the American 'melting pot." ${ }^{, 26}$ However, there is a lack of work on rural communities in general which clearly affects the amount available concerning WWII.

In this thesis, I set out to determine through a case study comparing the more rural Madison, Indiana, and urban Louisville, Kentucky, how the size of communities in a similar region affect the people, particularly the children, that resided there during WWII. To answer these questions, I chose to do oral history interviews with three girls who grew up in Madison during WWII and three girls who grew up in Louisville during the same time period. I used oral history methodology, which is defined by respected historian Valerie Raleigh Yow as "the recording of personal testimony delivered in oral form," because it provides the personal narratives that give life to history. ${ }^{27}$ As any researcher should do, I supplemented the oral histories with other primary and secondary sources. In the past, oral history has received criticism because it is not quantitative research, but I

\footnotetext{
${ }^{25}$ Tuttle, 91.

${ }^{26} \mathrm{Ibid}$.

${ }^{27}$ Valerie Raleigh Yow, Recording Oral History: A Guide for the Humanities and Social Sciences, $2^{\text {nd }}$ ed. (Walnut Creek, CA: AltaMira Press, 2005), 3.
} 
agree with Yow that recorded oral history provides "answers to questions that no other methodology can provide" because of the detail an interview can provide by sharing the thoughts, beliefs, and feelings of the interviewee. ${ }^{28}$ The oral history interview "offers the benefit of seeing in its full complexity the world of another," and this is particularly important when trying to understand World War II through the eyes of children. ${ }^{29}$ The experiences of children are hard to ascertain from the written record most obviously because they do not write such records, and those that are written rarely make it into the archives. Moreover, other usual sources such as newspapers and government records can at best only give an outside view of their experiences. Factual detail concerning dates is not necessarily crucial information to pull from the interviewees' narratives, because dates and information of that kind can be acquired through documentary research. Rather, the interviews are important because they obtain the details of how as children the women viewed their surroundings and experienced events. The thoughts and feelings of children during WWII can only be discovered through qualitative methods such as oral history interviews.

On the other hand, memory is also a concern when interviewing people years, and often decades, after an event occurred. Questions arise concerning the "reliability and validity" ${ }^{30}$ of interviewees' memories. For instance, how has the interviewee been influenced by outside sources since the event took place? According to Alice Hoffman in the Handbook of Oral History, studies show, however, that "once material has been

\footnotetext{
${ }^{28}$ Yow, 9.

${ }^{29} \mathrm{Ibid}, 23$.

${ }^{30}$ Alice M. Hoffman and Howard S. Hoffman, "Memory Theory: Personal and Social," in Handbook of Oral History, ed. Thomas L. Charlton, Lois E. Meyers, and Rebecca Sharpless (Lanham, MD: AltaMira Press, 2006), 278.
} 
coded into memory, it may be relatively stable." ${ }^{31}$ Forms of long-term memory can become essentially archival, meaning the memories "are readily recalled, change little, if at all, with the passage of time, and are resistant to enhancement by the presentation of recognition cues." 32 While the validity and reliability of memory can be a concern in certain instances, its hindrances are not strong enough or well-grounded enough to prevent the use of oral history.

The six interviewees were born between the years of 1929 and 1936, which made them range in age from five to twelve as America officially entered WWII. Not necessarily by my own doing, but rather due to the difficulties of locating women of this age group to participate in this project, it turned out that all the women were white and belonged to the middle or working social class. Therefore, the war is here seen through the lenses of young white, middle to working class girls growing up 50 miles away from each other in the Ohio River Valley region. Girls of a different race, class, and age but of the same locations may have had differing experiences, but from my research, I believe these girls experienced their communities during the war in a similar manner.

Before getting too involved with the comparison of the girls' lives during the war, a brief introduction to each narrator is needed. Mary Jane Sauley Bear was born on June 21, 1931, in Corydon, Indiana, but moved to Madison in 1937. She had one sibling, Norma Louise, who was seven and a half years older, but the two had a very close relationship growing up. Bear attended Lydia Middleton Elementary School in the West End of town, where she and her family resided at 949 W. Main St. Bear's mother never worked outside of the home but her father held various sales/business jobs until the war

\footnotetext{
${ }^{31}$ Ibid., 277.

${ }^{32}$ Ibid., 281.
} 
came at which point he took a war job. Bear had five cousins in the armed forces during WWII and a brother-in-law who was a B-17 pilot stationed in England. ${ }^{33}$

Nancy Jessup Jones was born in Madison, Indiana, on February 11, 1936. She grew up outside of town on a family farm located seven miles north off Highway 421, near the Jefferson Proving Ground (JPG). Jones was the youngest of four children by over a decade. Her sister Marjorie was twelve and a half years older, her brother Richard eleven and a half, and Norman 10 years older. Jones was very close to her sister who acted as her second mother, although she felt her brothers were not content unless they were teasing her. She went to North Madison Elementary School. Jones's mother was a schoolteacher prior to her marriage but did not work outside of their farm after she was married. Jones's father was primarily a farmer but he did work at the JPG during its construction phase, and her sister was also employed there. Both of Jones's brothers were drafted for WWII but were luckily stationed in the United States. ${ }^{34}$

On October 25, 1929, Caroline Lynch McCauley was born in Madison, Indiana, where she grew up, mainly in the home of her maternal grandparents with an uncle and cousin. McCauley's parents were divorced, but both lived in Madison up until the war. McCauley was close to her cousin Jeanette, who grew up with her in her grandparents' home, and the two acted like sisters. She attended Lydia Middleton Elementary School. McCauley's mother had always worked but took a war job at the JPG. She then traveled across the country doing war work with the same crew she had worked for at the proving ground. Her father also worked for a time as a guard and fireman at the JPG. During the

\footnotetext{
${ }^{33}$ Mary Jane Bear, interview by author, 28 Aug. 2006, Madison, Indiana, tape recording. Unless otherwise noted, all quotations and material come from interviews by the author, located in The Oral History Collection, University of Louisville Archives, Louisville, Kentucky.

${ }^{34}$ Nancy Jessup Jones, interview by author, 6 Nov. 2006, Madison, Indiana, tape recording.
} 
war, McCauley's uncle that lived with them was in the Navy on a destroyer in the Pacific, and she had three cousins that were in other branches of the armed forces. ${ }^{35}$

Marian Brennan was born in Louisville, Kentucky, on February 8, 1931, and has resided all her life in Jefferson County. Brennan had two older brothers, Louis Bertran, aka "Buddy," and Charles, aka "Charlie." Buddy was eleven years older and Charlie eight. Brennan grew up in the West End of Louisville in a cottage type house on West Kentucky St. between $26^{\text {th }}$ and $28^{\text {th }}$ Streets during WWII. She attended Holy Cross Catholic School from the $1^{\text {st }}-4^{\text {th }}$ grades, St. Benedict's Catholic School from the $5^{\text {th }}-8^{\text {th }}$ grades, and then Loretto High School. Her father worked at American Standard but her mother did not work until the war started, at which point she took a war job at the Charlestown Powder Plant as a sewing machine operator. Both brothers were overseas during WWII. One was in the Engineering Corp and the other a radar operator for the Air Force. Brennan had a first cousin who was a Gernan P.O.W. but made it back safely and another first cousin in the Navy who did not return. ${ }^{36}$

Rosemary Woods Block was born on January 22, 1930, in Louisville, Kentucky, and grew up in the West End of the city like Brennan in a two story shotgun house at $17^{\text {th }}$ and Dumesnil. Block had two brothers and a sister older than she and two brothers and a sister younger: J.L., Hugh, Peggy, Jane Carmel, Joe, and Jimmy. Block was closer to her younger siblings since they were closest in age to her. Block lived with her siblings, her parents, her maternal grandparents and an aunt all in the house at $17^{\text {th }}$ and Dumesnil. She attended St. Williams Catholic Church and School. Her father worked for a brewery during the war but died in a tragic accident shortly after the war ended. Her mother was

\footnotetext{
${ }^{35}$ Caroline Lynch McCauley, interview by author, 4 Dec. 2006, Madison, Indiana, tape recording.

${ }^{36}$ Marian Brennan, interview by author, 5 Feb. 2007, Louisville, Kentucky, tape recording.
} 
not employed. Block's two eldest brothers were in the service during WWII. Her eldest served as a secretary to a high-ranking official in Europe while the other served as infantry in the South Pacific. ${ }^{37}$

Ann Farris St. Clair was a Christmas baby born on December 25, 1931. She grew up mostly in the city of Louisville, although she spent parts of her childhood in Maud, Kentucky, where her parents were from and where they would return for periods of time when her father was laid off at Jeffboat or the Ford Plant. She lived in downtown Louisville in a very small 2 room apartment before her parents bought a house in the West End during the war. St. Clair's sister Wanda was two and a half years older than her and her brother Haynes six years older. They were all close as children but had different personalities. St. Clair attended Englehart Elementary School near Brook and Kentucky Streets. From there she went to Parkland and then Ahrens Trade School. Her mother took a war job sewing the ammunition bags at the Charlestown Bag Plant. Her brother was in the Marines during the war. ${ }^{38}$

This brief introduction into the lives of the six interviewees will establish the background for each girl during the war so effective comparisons and contrasts can be made. Without their stories, this thesis would be impossible, and for that I thank them.

\footnotetext{
${ }^{37}$ Rosemary Block, interview by author, 12 Feb. 2007, Louisville. Kentucky, tape recording.

${ }^{38}$ Ann St. Clair, interview by author, 28 Feb. 2007, Louisville, Kentucky, tape recording.
} 


\section{CHAPTER 2}

\section{MADISON, INDIANA, AND LOUISVILLE, KENTUCKY, DURING THE WAR}

This section will explore the backgrounds of Madison, Indiana, and Louisville, Kentucky, during the years leading up to World War II and during the war to provide a better understanding of the experiences the six girls had in their respective communities growing up. Both cities encountered much change in their economies during this time period, particularly concerning industry, but only those in Louisville were long-lasting.

During the first few years of World War II, the United States Office of War Information (OWI) searched for a small town that embodied the values for which America was fighting. The OWI wanted a town that was "typical of American small-city life." ${ }^{39}$ The OWI completed its search in 1943 when it discovered Madison, Indiana, a town on the banks of the Ohio River, located forty milles east of Louisville, Kentucky, and eighty miles west of Cincinnati, Ohio. ${ }^{40}$ Madison, a small town with a population of approximately 7,000, was supposed to represent to the rest of the world what America was truly like. The OWI's goal was to make a motion picture demonstrating "typical American living" to show to people in other countries. The movie was to feature the daily lives of Madison's citizens by focusing on "their customs, freedoms and daily routines, along with the town's architecture, Jefferson County farm life, the schools,

\footnotetext{
${ }^{39}$ Betty Johnson, "Madison: Typical American Town," The Courier Journal Roto-Magazine, 27 June 1943, Madison-Jefferson County Public Library Archives, 5.

${ }^{40} \mathrm{Ibid}, 6$.
} 
recreation facilities, and other facets" of daily American life. ${ }^{41}$ The OWI viewed Madison as a "cross-section of normal American life"42 except for its architecture, which they considered above average. George Milburn was chosen to write the movie due to his popular work on small town life. The plan was to translate the script of the film to thirty-two languages to stress Roosevelt's "Four Freedoms as exemplified in the lives of Madison's population., 43

It is unknown whether the film was ever translated into dozens of foreign languages, but the OWI's movie on Madison became a reality and illustrated the Four Freedoms, which were the freedom of speech and expression, freedom of every person to worship God in his own way, freedom from want, and freedom from fear. ${ }^{44}$ The movie, entitled The Town, was produced in 1945 by the OWI as part of their "The American Scene" series. It begins by giving a brief history of Madison, which was founded in the early 1800s and named after James Madison. In the 1940s, "like thousands of communities, [Madison drew] its life from its fields and farms" ${ }^{\text {45 }}$ while Main Street remained at the heart of the community. The Town highlights farmers and local citizens hard at work, residents worshipping freely at the local churches, and children learning at school and the public library. The freedom of speech and expression is emphasized through the scenes in the public library and the local newspaper offices, while the American judicial system is highlighted by a trial by jury in the local courthouse. The script points out that in America and other free countries, "The only thing that is secret is

\footnotetext{
${ }^{41}$ Ibid.

${ }^{42} \mathrm{Ibid}$

${ }^{43}$ Ibid.

${ }^{44}$ Franklin Delano Roosevelt, "Annual Message to Congress: The 'Four Freedoms' Speech," 6 January 1941, www.fdrlibrary.marist.edu/4free.html, 14 November 2006.

${ }^{45}$ The Town, Produced by the United States Office of War Information, 1945, in Madison in the Movies, Presented by The Cornerstone Society, 2006.
} 
the ballot." ${ }^{, 46}$ The movie focuses on the common people in Madison who have sent their sons overseas to keep freedom alive. The point of the movie is to show that residents of Madison and people like its citizens are working hard to "make this town and all towns like it, wherever they may be, free and secure forever." ${ }^{47}$

The Town demonstrates that the Office of War Information believed that Madison was a typical small American town. But to what extent did it remain so after the war? The war in Europe and then the American involvement in the war transformed certain aspects of life in Madison, such as manufacturing and war service without transforming the small town life that was worth going to war over. The Town portrayed Madison's small town life as static, and thus did not address the changes the war brought to the community, even if those changes were not permanent.

A few scholars have researched other towns similar to Madison in the WWII era. New Castle, Indiana, a relatively small city with a population of 16,620 in 1940 , has been the subject of one such study. ${ }^{48}$ New Castle lies due north of Madison, Indiana, by around 90 miles. Bruce C. Smith's The War Comes to Plum Street provides insight to a few of New Castle's families whom he believes "represent something very much like average Americans of their day, ${ }^{, 49}$ similar to The Town's Madisonians. Smith tells the story of these families during the Great Depression and World War II eras. His main goal is to "look at the war through the eyes of people who lived through it." ${ }^{50}$ Smith provides good insight into the daily lives of New Castle residents during WWII and the

\footnotetext{
${ }^{46} \mathrm{Ibid}$.

${ }^{47} \mathrm{Ibid}$.

${ }^{48}$ Donna Andriot, ed., Population Abstract of the United States, 1999 ed. (Farmington Hill, MI: The Gale Group, 2000), 180.

${ }^{49}$ Bruce C. Smith, The War Comes to Plum St., (Bloomington: Indiana University Press, 2005), xii.

${ }^{50}$ Ibid., xi.
} 
changes these citizens and their community underwent. For instance, Smith describes the industry of New Castle and examines the shifts of several manufacturers, particularly the Chrysler Corporation, during WWII to full wartime production. This analysis aids in the comparison to the wartime industrial shift in Madison, Indiana.

Bob Greene, author of Once Upon a Town: The Miracle of the North Platte Canteen, also tells the story of a small town in the Midwest, but Greene's story has a twist. North Platte, Nebraska, was in most ways the average Midwest town, just like New Castle and Madison. North Platte was an isolated community of approximately 12,500 residents in $1941 .^{51}$ It had the typical downtown merchant area with the corner drug-store, local newspaper, and high school. North Platte's young men were shipped off to war like the other young men in the country. In some respects, most towns in America sacrificed for the war, but what made this seemingly average town extraordinary was the generosity of its citizens who turned their train station into a canteen to greet the soldiers passing through. Although the soldiers only remained for ten minutes, the North Platte community provided them with entertainment, food, cigarettes, magazines, and anything else they could get their hands on. Six million soldiers passed through the North Platte Canteen during the war, and each one of them was greeted by North Platte citizens. Greene's purpose in writing his book was to tell the story of the North Platte Canteen, but interwoven within his narrative are crucial details about small town life and the changes it experienced during World War II. North Platte, like New Castle and Madison, although extraordinary during the war, returned to its pre-war state once WWII ended. ${ }^{52}$

\footnotetext{
${ }^{51}$ Andriot, 394.

${ }^{52}$ Bob Greene, Once Upon a Town: The Miracle of the North Platte Canteen, (New York: Harper Collins Publishers, Inc., 2002).
} 
Both Smith and Greene provide insight to small town life, both ordinary and extraordinary. However, there is still a gap in the literature concerning how small towns and communities themselves were transformed by the war and how this transformation either permanently changed the city or not. Smith and Greene's work focuses on certain people or things as opposed to the cities themselves. This section on Madison will demonstrate how WWII affected the town without changing its inherent nature. The continuity of these small town characteristics during WWII may be a trend of many similarly sized American communities that has yet to be properly investigated and studied. The example of Madison's transition during the war and the return to its pre-war state begins to fill the gap in literature specifically concerning small American towns during the Second World War.

On the eve of WWII, Madison was very much "a Saturday town." ${ }^{53}$ Families would drive into town from their farms to do their weekly shopping and visit with those who lived in town. ${ }^{54}$ Madison businesses included grocery stores, drugstores, movie theaters, ice cream shops, restaurants, bars, shoe stores, hardware stores, and furniture stores, to name a few. It was not necessarily a booming metropolis, but it did have everything a small town and the surrounding rural area needed to survive. Citizens were involved in the community churches and local organizations such as sewing clubs and the American legion. The local high school sports were popular with Madison residents as

\footnotetext{
${ }^{53}$ Madison 1936-1938, Preserved by Harold Lohrig, in Madison in the Movies, Presented by The Cornerstone Society, 2006.

${ }^{54}$ Jones.
} 
were the activities of Hanover College, which was located just a few miles outside of Madison in the neighboring community of Hanover. ${ }^{55}$

The daily newspaper, The Madison Courier, covered the local daily news, and provided regional and national news to the residents of Madison and the surrounding area. With the tense situation and eventual war in Europe, The Madison Courier began to cover war news by providing various articles on the events in Europe and the Pacific. ${ }^{56}$ At the end of summer 1939, while the world was on the brink of war, Americans were advised not to travel to Europe and plans were made to "rush home thousands of United States citizens if war [broke] out in Europe. ${ }^{, 57}$ However, life had yet to change for Madison residents who were preparing to send their children back to school and watch the newly released The Wizard of $\mathrm{Oz}$ in Technicolor at the local Ohio Theater. ${ }^{58}$

Once war broke out in Europe on September 3, 1939, Madison began to experience some changes. Of course war news appeared in the papers and the citizens speculated if the United States would eventually be drawn into the conflict. Even before the U.S. officially ended its neutrality, the first major effect of the war in Madison was the opening of a proving ground to test ammunition outside of town. The United States War Department had been testing military fuses, bombs, grenades, and primers along with other explosives made to use as weapons for war at a facility in Aberdeen, Maryland. The facility at Aberdeen "was inadequate for the increased testing demanded by the United States' updated project of manufacturing ordnance that the threats of war in

\footnotetext{
${ }^{55}$ The Madison Courier, 11 August 1939- 2 December 1939, Microfilm Reel 207, Madison-Jefferson County Public Library Archives.

${ }^{56} \mathrm{Ibid}$.

57 “Americans Are Called Home," The Madison Courier, 23 August 1939.

${ }^{58}$ The Madison Courier, 11 August 1939- 2 December 1939.
} 
Europe posed to our government, ${ }^{, 59}$ so the War Department began to look around for a larger area to test military weapons.

The War Department started the inspection of southeastern Indiana as a possible location site as early as 1938. Certain requirements for the ammunition testing ground had to be met. For instance, "an inland area was needed where weather conditions were favorable throughout the year. This area [needed to] be without sizable settlements, but with adequate rail, highway, and transportation." ${ }^{60}$ The testing ground had to be sufficient in size for the safe testing of "huge military weapons like anti-aircraft guns and Howitzers. Due to the earth's rotation, a south to north firing line needed to be established to produce the most accurate testing." ${ }^{61}$ The land right outside Madison met all the War Department's requirements. On top of that, "it was accessible to principle industrial, military and manufacturing centers of the Midwest, including the world's largest smokeless powder plant at Charlestown, Indiana, only thirty miles down the Ohio River."

During a meeting in Washington, D.C., on October 8, 1940, "a 55,000 acre area of land in southeastern Indiana was chosen as the site for the planned national defense project." ${ }^{, 63}$ The land chosen created a fan-shape of flat farm land, rolling pastures, and groves of trees and wooded areas that was seventeen miles long, three miles wide at the southern end, and seven miles wide at the northern end. The land spanned through

\footnotetext{
${ }^{59}$ Sue Baker, Echoes of Jefferson Proving Ground: For Defense of Our Country, (Indianapolis: Guild Literary Services, 1990), 1.

${ }^{60} \mathrm{Ibid}$.

${ }^{61}$ Ibid., $1-2$.

${ }^{62}$ Ibid., 1.

${ }^{63} \mathrm{Ibid}$., 2. Sources printed by the JPG themselves state that the on October 8 it was acknowledged that another proving grounds facility was needed but the decision to construct this site wasn't made until December 1940. All sources stating these dates are secondary, so I'm not sure which is correct.

Regardless, the decisions concerning the JPG officially began within that 2-3 month stretch in late 1940, with the JPG becoming a reality by the end of December of the same year.
} 
Jefferson, Ripley, and Jennings counties beginning near the town of Wirt, Indiana, which was located four miles north of Madison on State Road 7 and extending east three and a half miles to Old Michigan Road. From there, the boundaries headed north near Holton, Indiana, and then west to Butlerville and back south again to Wirt. The local citizens who lived on the land being inspected by the government were unaware of the process of selection occurring because it was a well-kept secret. They noticed an increase in airplane traffic and army vehicles near their homes but believed the sightings unimportant at the time. The details were revealed on December 6, 1940, when " "behind barred doors' twenty-two federal, state, and local officials gathered at the Jefferson County court house to make the announcement. Purchase of the land was to begin in the southern, or narrow, end of the tract in Jefferson County."

News of the plans for the proving ground was released to the public via The Madison Courier by December 10, 1940. The article reported that the proving ground would be used to test tanks and other weapons and that the cost would range from $\$ 6,000,000$ to $\$ 8,000,000$. Storage facilities and administration quarters were the main structures needed for the project immediately. The sound recorders and other devices used to measure the velocity of the ammunition were to be the most expensive aspect of the project. Around eight-hundred workers were expected to be employed by the proving ground after its completion. Unofficial reports circulated that the Pennsylvania Railroad Company would make changes to railroad tracks in the area, work loads might increase, and a connection would be made to form a direct rail line between the new proving

\footnotetext{
${ }^{64} \mathrm{Ibid}$., 2. An article from The Madison Courier said the meeting was held in the courthouse on December 9.
} 
grounds, the powder plant in Charlestown, and Fort Knox, Kentucky. ${ }^{65}$ However, this was simply early speculation.

Unfortunately, 500 farm families were located on the ground chosen for the project and all were expected to relocate from the Monroe township area, which included the towns of Belleview and Bryantsburg. The local residents had to leave behind their homes, five township schools, six churches, and several cemeteries where relatives were buried. It was announced that they would be reimbursed for "everything the landowner [was] unable to move and for removal of coffins from the cemeteries to other sites." Original estimates from the Paul L. McCord real estate firm out of Indianapolis that was hired by the government to act as agent in the sales said that options on farms would be discussed within a few short days. After the options were taken, the families would have thirty days to vacate their property. The real estate firm hoped to remove everyone from the newly acquired property within forty-five days. ${ }^{67}$ Everything from the announcement of the JPG to the removal of the residents on the land happened in a hurry. According to the local history of the JPG, the "transformation from quiet, rural neighborhoods to the rumble of the first $75 \mathrm{MM}$ test round took only 155 days. It was a sacrifice to the gods of war...for defense of our country, and it was done with such ruthless, inexorable haste that the lives of hundreds of families were changed forever in less time that it takes to grow a crop of corn., 68

The news of their relocation came as a shock to the 2,000 residents of the proving ground lands. Many were long-time residents of the neighborhoods and family farms

\footnotetext{
65 "Madison Project Gets Formal O.K.: Proving Ground Land Purchase to Start at Once-500 Families to Move," The Madison Courier, 10 December 1940.

${ }^{66} \mathrm{Ibid}$.

${ }^{67}$ Ibid.

${ }^{68}$ Baker, 3.
} 
while others had just recently built there. ${ }^{69}$ Regardless, they were forced to give up their homes and property. The Farm Security Administration was in charge of the "land transactions to prevent speculation in the attaining of the 600 individual pieces of property."70 The FSA was afraid certain "“scalpers and chiselers",71 would attempt to profit from a potentially confusing and large enterprise, which happened to some extent. The first step of the buying/selling process was for the home and land owners to estimate the value of their property, based on "current market prices and productivity of the acreage." 72 The goal was to give the landowners a fair deal and to work with them to satisfy both parties. Unfortunately, after the government realized they were going over budget with their early offer of $\$ 90 /$ acre, the agents "began to cut corners."73 The landowners complained but eventually capitulated and "became the losers in this perplexing situation." ${ }^{74}$ Reports and claims surfaced that the real estate and title companies involved in the transactions billed the government "“exorbitant and unjustified fees and commissions in connection with the purchase... of land for the Proving Grounds." 75 The United States Assistant Attorney General Norman Littell halted the government's title acceptance with the proving grounds until the situation was investigated. He stated, "'Making excess profits during a national emergency offends one's sense of citizenship." ${ }^{\prime 76}$ Eventually, the commission for the real-estate and the title companies' prices were settled with the government, and the process continued.

\footnotetext{
${ }^{69}$ Ibid., 57-59.

${ }^{70}$ Ibid., 60.

${ }^{71}$ Ibid.

${ }^{72} \mathrm{Ibid}$.

${ }^{73}$ Ibid., 61.

${ }^{74} \mathrm{Ibid}$.

${ }^{75}$ Ibid., 63.

${ }^{76}$ Ibid.
} 
Apparently, "the accusations of corruption evaporated with satisfactory solutions, allowing all persons involved to perform their duties competently." 77

The deadlines for the completion of the Jefferson Proving Ground were bumped up in mid-January 1941 to late April or early May, and the families were expected to leave as soon as possible. By the end of March 1941, only seventeen families remained out of the original inhabitants of the land, and only three of those were residents of Jefferson County. The Jefferson County families were required to evacuate their homes by April 1. Most of the families who had already left their homes "sought to acquire new homes as near as possible to the communities in which they had resided for years and many for a lifetime." ${ }^{78}$ Some former residents moved into the town of Madison while a smaller number moved farther away. ${ }^{79}$

By April, the construction on the proving ground was a quarter finished but was also 25 percent ahead of the planned schedule. Around 2800 men were working on the construction of the JPG but once everything was completed, only 800 employees were expected to be fully employed there, including both men and women. ${ }^{80}$ Women were hired at the JPG to perform typical women's secretarial work but were later trained in other jobs "to replace all men called into the armed services." 81 On May 10, 1941, the first ammunition rounds were fired at the JPG. ${ }^{82}$ In the spring of 1942, the JPG'S construction reached its height with 5,000 employees working to complete the project. This high number, however, does include construction workers and not only local

\footnotetext{
${ }^{77}$ Ibid., 65.

78 "JPG Dwellers Vacate," The Madison Courier, 27 March 1941.

${ }^{79}$ Ibid.

80 "Only Seven Families Remain in JPG Tract," The Madison Courier, 19 April 1941.

${ }^{81}$ George Henry Kast, "History of Jefferson Proving Ground from December 30, 1940-December 31, 1942," Vol. I, January 1943, Madison-Jefferson County Public Library Archives, 33.

${ }^{82}$ Ibid., 2.
} 
workers with steady jobs at the JPG. Outside construction workers were often brought in from Cincinnati and Louisville when their firms were contracted for a specific project, but returned home when the project was completed. ${ }^{83}$ Over time, sixty-four miles of road were added to the area, a large parking lot was created, bomb shelters were erected, an airport was completed, and "endless miles of railroad track were laid to connect the ammunition storage and loading yards. ${ }^{84}$ Construction to the JPG continued throughout the war to expand the facilities and "create the most productive and efficient ammunition testing facility possible." Thus, the JPG employed more people than originally anticipated. ${ }^{85}$ By early 1943, 1200 civilian employees worked for the Ordnance Department at the JPG, along with twenty-five Ordnance Officers and five Air Corps Officers. Seventy-five men consisting of Air Corps Mechanics, Weather Squadron, and Medical Detachment worked with the testing of the bombs and pyrotechnics. ${ }^{86}$

The official military mission for the JPG "was to plan, conduct, and report the test results for all types of ammunition, ${ }^{, 87}$ although in reality, it was a little more complicated than that. High tech equipment was used to record data on the tests, and "the results were studied to determine the acceptance or rejection of ammunition to be used by the United States military." 88 For instance, fire bombs were tested in the JPG, and then of course used famously on raids in Japan and Germany. ${ }^{89}$ The JPG was under close surveillance

\footnotetext{
83 "JPG Dwellers Vacate."

${ }^{84}$ Baker, 102.

85 "Construction at JPG Halted: About 300 Outside Laborers Affected by Government Order," The Madison Courier, 13 August 1945, and quote in Jefferson Proving Ground Golden Anniversary Booklet, 10 May 1991.

${ }^{86}$ Kast, 3 .

${ }^{87}$ Baker, 104.

${ }^{88}$ Ibid.

${ }^{89}$ Ibid., 108.
} 
by security guards and a fire department was on call 24 hours a day to ensure the safety of all working there.

While the JPG obviously changed the lives of the people living directly on the land acquired by the government, it also affected the community of Madison as a whole. It provided local people with jobs, which helped many families financially since the economy was still unsteady from the Great Depression..$^{90}$ The JPG drew workers from the nearby farms, local stores, and industries because of its high pay. The County Agent, L.P. Guyer, stated, “'We have lost a good many of our good farmers to the proving grounds. But, owing to the fact that we had a surplus of rural population, we are not greatly concerned.",91 The JPG was credited for raising Madison's "general level of wages." ${ }^{92}$ The pay scale in Madison in the early 1940s was disproportionately low compared to similar rural communities, but the JPG had to raise wages to keep employees lured by the "higher rates of pay given by war contractors in the cities of Louisville, Cincinnati, and Indianapolis." ${ }^{.93}$ By the end of 1942, the cost of living in Madison and the surrounding area began "to approximate more nearly the cost of living in the area as a whole, and the original differential between it and other towns of its size [was] reduced. ${ }^{, 94}$

Citizens of Madison living near the edge of the proving ground were also affected, although not quite as dramatically as those actually removed from their property. Nancy Jessup Jones was just a young girl of four or five when construction of the JPG began. Her family lived on a 90-acre farm in Madison just on the other side of

\footnotetext{
${ }^{90}$ McCauley.

91 Johnson, 8.

${ }^{92} \mathrm{Ibid}$.

${ }^{93}$ Kast, 181.

${ }^{94}$ Ibid., 183.
} 
the fence from the JPG. She remembers hearing the bombs being dropped and the testing of the guns. It did not cause much damage to their property except that occasionally the force would shake the house. Once in a while fires would occur as a direct result of an ammunition test, and they would spread rapidly. Jones recalled being scared of the fires, which were sometimes small and sometimes quite large. However, the addition of the JPG to the Madison community was a positive thing for Jones's family as it was to many other local residents. Her father worked there during the original construction phase for extra money to supplement his farming income, and her sister worked there as a stenographer during the war. ${ }^{95}$

The Jefferson Proving Ground also gave Madison citizens a sense that they were helping out with the war effort first by residents giving up their homes and second by working at the facility. Although the residents that sacrificed their homes and properties were sad to see their community abolished, they realized they were helping the war cause. Mrs. Edith Chaplin published a poem in the Madison Courier summing up the feelings of the former residents of Marble Corner, one such community destroyed by the JPG. Chaplin wrote:

Of course we love our country, And want to do our bit, But of all the desolate places I have ever seen yet, Is our dear loved Marble Corner since bought by the government...

They have also built a fence and are waiting for us all to vacate. And when we all get out they will close and lock the gate. Then all we will have is a memory of the homes where we were born. But I am sure we will never forget this $1941 .^{96}$

\footnotetext{
${ }^{95}$ Jones.

${ }^{96}$ Edith Chaplin, "Marble Corner: A Lament," The Madison Courier, 21 March 1941.
} 
Other local residents such as the workers of the Proof Division of the JPG felt "justly proud of its contribution to the winning of the war. Each individual in each unit or branch [could] honestly state, "My efforts have helped to shorten the war." ${ }^{97}$ Caroline McCauley was a young girl when the JPG was built in Madison, and both of her parents worked there at different points during WWII. McCauley's mother did regular office work in Madison prior to the proving grounds existence, but once she began work at the JPG, she felt she was contributing to the war effort and supporting her brother who was in the armed services. ${ }^{98}$

The Jefferson Proving Ground was not the only industry providing war jobs for Madison's citizens. Local industry shifted to wartime production, and like the JPG part of this shift occurred prior to the United States full entrance into WWII. Then, once the attack on Pearl Harbor occurred, several industries went to 100 percent wartime production, similar to the Chrysler Plant in New Castle, Indiana. The International Business Machines Corporation put out an ad soon after Pearl Harbor was attacked reflecting on the new "trend of thought" 99 in the United States. The shift occurred from people prior to the attack of thinking in terms of "I" to people now thinking in terms of "we." The president of the corporation sponsoring the ad stated, "Our slogan is WEALL, which means every loyal individual in the United States! We are facing a long, hard job, but when the United States decides to fight for a cause, it is in terms of WEALL, and nothing can or will stop us." 100 This slogan "WE-ALL" was soon applied to

\footnotetext{
${ }^{97}$ Paul W. Reed, "History of the Jefferson Proving Ground From 1 July 1945 to 30 September 1945," Vol. XII, November 1945, Madison-Jefferson County Public Library Archives, 79.

${ }^{98}$ McCauley.

${ }^{99}$ Advertisement from the International Business Machines Corporation, The Madison Courier, exact date unknown, early 1940s.

${ }^{100}$ Ibid.
} 
workers entering the workforce to help with the defense of this country. The city of Madison prepared itself "for an all-out effort to aid the national defense program."101 The local residents quickly became "war-minded, having realized since [Pearl Harbor] that the [Japanese] mean business."

Meese, Inc. was one such local business that received government contracts for wartime production. In 1931, Edward W. Meese founded the company in Madison, Indiana. Meese, Inc. "pioneered the design and development of canvas carts and containers for the laundry industry and was among the first companies to manufacture with fiberglass and polyethylene plastics."103 As the company continued to grow throughout the years leading up to WWII, it expanded into larger buildings before settling into "a large modern factory building," 104 formerly the Eagle Cotton Mills, ${ }^{105}$ located on St. Michael's Avenue in Madison. During the war, however, the Air Cushion Shoe Company occupied the top two floors. ${ }^{106}$

Meese, Inc., was one of Madison's leading industries when the US fully entered the war. Less than a week after Pearl Harbor, Meese, Inc. was "operating practically 100 percent on government contracts."107 During WWII, they produced combat packs, coke bags, war goods, water/blister bags, dispatch cases, canvas baskets, bedding rolls, rucksacks, and insulated containers. Meese, Inc. also "helped develop the original rucksack for ski troops."108 The government purchased thousands of laundry baskets and

\footnotetext{
101 "Local Plants Turning Out Defense Products," The Madison Courier, 12 December 1941.

102 Ibid.

${ }^{103}$ www.meeseinc.com/about/shtml, "About Us," 15 November 2006.

104 "Meese, Inc.: In Retrospect," The Madison Courier, 1954.

${ }^{105}$ Johnson, 8.

${ }^{106}$ Press Release from Paul Entin, Media Relations for Meese Orbitron Dunne Company, 20 November 2006.

107 "Local Plants Turning Out Defense Products."

${ }^{108}$ Press Release from Paul Entin.
} 
trucks from Meese, Inc. during wartime. In many instances, Meese's competitors refused to bid on government contracts so "'many government orders were literally forced on the Meese company by the Jeffersonville Quartermaster Depot."109 This worked in Meese's favor because they received a larger allotment of canvas and steel since they were contracted through the government, and they actually received more materials than all of their competitors together. Unfortunately, since Meese was so immersed in government business during the war, they lost some distributors business to their competitors. ${ }^{110}$ Because of the shortage of workers due to the war, Meese, Inc. advertised for "sewing machine operators, trimmers, and inspectors for essential war work." 111 By 1943, they were employing around 200 people, ${ }^{112}$ many of whom were women. Perhaps to attract and keep these workers, the firm also established "the first IRS-approved pension plan in the state of Indiana." 113

Meyers and Son Manufacturing Company was another leading industry in Madison, along with Meese, Inc., that shifted to wartime production and mainly produced goods only for the government after Pearl Harbor was attacked. ${ }^{114}$ H.P. Meyers and his son D.P. Meyers founded the business in 1932 in Martinsville, Indiana, before moving their company to Madison in 1937. They originally "manufactured lined denim jackets, dungarees and high back denim overalls." 115 However, "just prior to the start of WWII, Meyers and Son went into full government production and began a night shift making leggings, bed rolls, ruck sacks, dispatch cases, and shovel covers for the soldiers from

\footnotetext{
${ }^{109}$ Ibid.

${ }^{110}$ Ibid.

${ }^{111}$ Meese, Inc. Advertisement, The Madison Courier.

112 Johnson, 8.

${ }^{113}$ Press Release from Paul Entin.

${ }^{114}$ Ibid.

${ }^{115}$ Steve White, "Quality Cited by Meyers' Worker," The Madison Courier, 28 January 1989.
} 
1939 to $1945 . " 116$ Meyers and Son actually held a joint contract with Meese, Inc. on the production of haversacks and rucksacks. ${ }^{117}$

The War Department advised both Meese, Inc. and Meyers and Son to keep records and fingerprints of all their employees and to "guard the plants against possible sabotage attempts." 118 The government also recommended that these two plants and others like it around the nation holding government contracts install floodlights around their facilities and erect fences. Both plants were under surveillance throughout the entire day and night. In December of 1941, the plants had already heeded the War Department's advice concerning fingerprinting and were in the process of erecting floodlights. ${ }^{119}$ Both plants were located in the East End of town but not segregated from the residential areas, so it is likely that citizens could see the security changes the factories were installing.

Although the war atmosphere and industry transformed Madison during the war, it for the most part returned to its pre-war state of a mostly agricultural area with the usual manufacturing and commercial enterprises for a town of its size and nature after WWII was over. ${ }^{120}$ With the war officially over in Europe and the fighting coming to a close in the Pacific, "the war department [initiated] steps to reduce the nation's military structure to a peacetime basis. Scores of factories engaged in the production of materials of war [were to] immediately suspend war work and [would] be reconverted to peacetime activity." 21 This included military facilities such as the JPG. The Jefferson Proving

\footnotetext{
${ }^{116} \mathrm{Ibid}$.

117 "Local Plants Turning Out Defense Products."

${ }^{118}$ Ibid.

${ }^{119}$ Ibid.

${ }^{120}$ Johnson, 8.

${ }^{121}$ Ibid.
} 
Ground temporarily halted further construction projects expanding their facilities immediately after the atomic bombs were dropped in Japan. ${ }^{122}$ Just days after V-J Day was announced, the JPG went to a "stand-by basis." ${ }^{\text {"23 }}$ Employees at the JPG were drastically reduced immediately after WWII ended. By the end of September 1945, only 353 employees out of 1200 had not received reduction notices, resigned, or transferred to a different government agency. ${ }^{124}$ From that point on, the JPG's "history is punctuated by periods of intense activity followed by rapid downturns." ${ }^{25}$ The JPG, however, unlike other government wartime facilities, remained at least somewhat active for almost half a century before it was discontinued as an ammunition testing site. ${ }^{126}$

The JPG drastically altered the lives of the residents it uprooted, but it also provided Madison with jobs during the war and for the next fifty years, although the employment numbers fluctuated. Within five years of the end of WWII, only fifty-one employees remained at the JPG, but during the Korean War the JPG topped employment with 1,750 workers. Fifteen years later during the Vietnam War, the proving ground employed close to 1,000 people but for the next three decades employment numbers hovered between approximately $385-500$ workers. ${ }^{127}$ The JPG provided jobs to the community but did not necessarily alter the small-town nature of Madison because the workers the JPG hired were mostly local citizens and the construction war workers, often from Cincinnati and Louisville, did not remain in the area after the war ended. In fact,

\footnotetext{
122 "Construction at JPG Halted: About 300 Outside Laborers Affected by Government Order."

123 "JPG Prepares to Limit Operation: War Department Instructions Say Reduce to Peacetime Basis When Japs Quit," The Madison Courier, 14 August 1945.

${ }_{124}^{12}$ Reed, 9.

${ }^{125}$ Jefferson Proving Ground Golden Anniversary Booklet, 10 May 1991.

${ }^{126}$ Ibid.

${ }^{127}$ Ibid.
} 
Madison's population increased by less than 600 people in the entire decade from 1940 $1950 .^{128}$

The same applies for the other industrial shifts in Madison that occurred due to the war. Both Meese, Inc. and Meyers and Son shifted their production back to the prewar state and also headed down new avenues of production. The companies no longer worked with government contracts as a main function of their business. As production returned to the pre-war status, so did the size of the industries. Within days of the official end of the war, the government contracts between Meese, Inc. and Meyers and Son were severely cut back or terminated, thus leading to a reduction in wartime personnel. All of Meyers and Son's contracts were cancelled while four of Meese, Inc.'s were terminated and a fifth was also affected. Close to 200 Meese, Inc. workers, most of who were women, were dismissed due to the cessation of the production of water bags and combat packs. At Meyers and Son, “the stoppage order...dropped 75 women from the payroll." 29 After dismissing 200 workers, Meese, Inc. was employing just a few more workers than prior to WWII.

Neither Meese, Inc. nor Meyers and Son shut down after their government contracts were terminated. Meese, Inc. immediately began planning for reconversion, which entailed focusing on production of civilian goods along with expanding new product lines which would "boost the number of employees substantially."130 Meese, Inc. still has a plant in Madison although they have merged to become the Meese

\footnotetext{
${ }^{128}$ Andriot, 180.

129 "Cutbacks Bring Work Stoppages: Meese, Inc. Releases 200 and Meyers 75 After Cancellations," The Madison Courier, 18 August 1945.

${ }^{130} \mathrm{Ibid}$.
} 
Orbitron Dunne Company. ${ }^{131}$ Meyers and Son returned to their peacetime production of work suits and coveralls but the factory was unsure how many employees they would require after the war because of available materials. ${ }^{132}$ Meyers and Son continued production until 1997 when they went out of business permanently. ${ }^{133}$

Madison's social and community life underwent a transformation during the war, but like local industry, did not change the nature of the town. The war rather strengthened the community by giving the citizens a common goal. Residents of Madison participated in the war effort and civilian defense through various clubs, social organizations, religious affiliations, and schools. The local Red Cross chapter geared up for the war effort by organizing Canteen Corps, training Nurses Aides, and sponsoring war fund drives. Other local groups participated in sewing efforts for the Red Cross and donated proceeds to the charity. For instance, a local resident hosted a large card party with the intention of donating the proceeds to the Red Cross. ${ }^{134}$ Similar civilian defense programs and groups were initiated soon after the war began to orchestrate local citizens to protect their community. The community was divided into fourteen zones, each equipped with their own air raid wardens. These wardens along with auxiliary firemen and policemen were instructed in first aid courses "to provide immediate temporary care by trained persons, until a doctor arrives, in case of injuries to civilians during an attack by the enemy." $" 135$

\footnotetext{
${ }^{131}$ www.meeseinc.com.

132 "Cutbacks Bring Work Stoppages."

${ }^{133}$ Memo about Meyers and Son Manufacturing Company, Madison-Jefferson County Public Library Archives.

134 "Plan Benefit Party," The Madison Courier, 3 June, 1942, and "Report Red Cross Work," The Madison Courier, 7 Jan., 1944.

135 "Take Up First Aid," The Madison Courier, 18 Aug., 1942.
} 
Other local clubs like the Kiwanis Club shifted efforts to the war by supporting "an all-out movement for victory, [backing] the war effort in every way possible and [building] morale," while the local Rotary Club sponsored guest speakers such as foreign war correspondents. ${ }^{136}$ Rotary also created a war service committee to obtain names and addresses of enlisted men in order to send a remembrance to each soldier. ${ }^{137}$ Many organizations participated in local bond drives, such as the Fraternal Order of Eagles who purchased $\$ 8,000$ worth of bonds in two bond drives alone. Staff at the local library began recording Jefferson County's activities during WWII by saving newspapers clippings and entering them in a scrapbook. They saved homefront articles covering war bond sales, the Red Cross, civilian defense, scrap materials collection, and rationing. The staff also kept military news articles like the lists of local men and women in the service, weddings, deaths, and letters from the armed forces. They believed their recordings would provide "a very valuable war record of Jefferson county, but [would] prove interesting to the boys and girls in the service when they [came] home. ${ }^{138}$

School children were also involved with the war effort through groups such as the Junior Red Cross and Boy and Girl Scouts. Through the Junior Red Cross, Madison children collected coat hangers and "completed various articles, tray cards, joke books, crossword puzzles, carnival caps, and memo pads which [were] shipped to Camp Atterbury.”139 Local Boy Scouts were involved with collected waste paper and rubber. The Madison Courier prodded the community into action by stating, "You can help

\footnotetext{
136 “Kiwanis Lists Aims," The Madison Courier, 7 Jan., 1944, and "Foreign Newsman to Speak Before Rotary," 3 June 1942.

137 "Many Names Missing: Rotary War Service Group Appeals for Help," The Madison Courier, 10 Aug., 1942.

138 “Will Keep Clippings," The Madison Courier, 17 Jan., 1944. Unfortunately for my research, I was unable to locate any completed scrap books from the war era.

139 "Report Red Cross Work."
} 
scouts help Uncle Sam to unity and victory."140 The Girls Scouts were also collecting waste materials such as excess cooking fats saved by local housewives. ${ }^{141}$

Churches and church groups held special services and activities to help support the local members of the armed forces and their families. The Westfork Baptist church hosted a candlelight dedication for "the boys of the community who [were] in the services of the army, navy, or any other branch of the U.S. services."142 The North Madison Methodist church held a dedication for their new church service flag along with a presentation of new American and Christian flags for which they "hoped the mothers of all the boys in the service [would] be present to represent their sons."143 Churches like the local Trinity church held talks on subjects such as "The Church After the War."144 Some women's church groups participated in the war effort by volunteering their time to sewing for the Red Cross. ${ }^{145}$

Servicemen's needs in the area were not ignored by the Madison community, and the organization of an USO service club was started in August 1942. The USO, which was to benefit members of the armed forces and defense workers, was located at Holwager Memorial Center. Madison's USO was to be laid out in conjunction with the state organization guidelines. Local volunteers such as ministers and groups like the Junior Civics Club pledged to work at the USO. A local judge also recommended that the USO provide encouragement and parting gifts to show the servicemen "how warmly their homefolks felt towards them and how really sympathetic they were."146

\footnotetext{
140 "Scouts Collect Rubber," The Madison Courier, 3 June, 1942.

141 "Will Not Collect Fats," The Madison Courier, 6 Jan., 1944.

142 "To Honor Soldiers," The Madison Courier, 13 Jan., 1944.

143 "To Dedicate Flag," The Madison Courier, 21 Jan., 1944.

144 "Prayer Meeting at 7:30," The Madison Courier, 5 Jan., 1944.

145 "Sew for Red Cross," The Madison Courier, 18 Aug., 1942.

146 "USO Organized," The Madison Courier, 19 Aug., 1942.
} 
Madison was affected by the addition of the Jefferson Proving Ground but the JPG did not transform Madison as a whole. Neither did the transition of Madison's leading industries to wartime production nor the focus on war activities by the varying social clubs and churches. Daily life continued in much the same manner for the majority of Madison's residents, even if they had new jobs during and after the war or moved to a new location. The war undoubtedly changed people due to their personal or family involvement in the war, but the war did not alter the community of Madison as a whole. It still had the same number of churches, schools, and clubs as it did prior to the war. ${ }^{147}$ There was not an influx of people moving into the area that remained after the war. The residents of Madison, however, did work hard during the war, as The Town accurately stated, "to make this town and all towns like it, wherever they may be, free and secure forever." small town intact.

Louisville, Kentucky, on the other hand, experienced a more lasting community change. The city had a population of 307,745 in 1930 and 319,077 in 1940, which was significantly larger than that of Madison. ${ }^{149}$ Like many other cities in the United States, Louisville experienced the tumultuous times brought on by the Great Depression. The city had a particularly rough decade economically but also physically when the city experienced the greatest flood of its history. In early 1937 the Ohio River, which created the northern and western boundaries of Louisville, crested at 51.1 feet, and over 60

\footnotetext{
${ }^{147}$ Hoffman's City Directory of Madison, Indiana, (Quincy, IL: The Hoffman Directories, 1939, 1942, and 1947).

148 The Town.

${ }_{149}$ John L. Andriot, ed., Population Abstract of the United States, (McLean, VA: Andriot Associates, 1983), 304.
} 
percent of the city was inundated with flood waters. ${ }^{150}$ Louisville would not officially be rescued from its struggling economic state until World War II. The war transformed Louisville from economic duress to a booming industrial city. Unlike the small community of Madison, Indiana, Louisville experienced social and industrial changes that were permanent.

When the Great Depression began with the stock market crash of October 29, 1929, many of Louisville's economic elite were not overly worried, and viewed the crash as "a healthy corrective to an overheated market."151 Louisville investors had faith in James B. Brown's BancoKentucky Corporation and displayed their faith by purchasing more stock in the company. But, Louisville began to face the intensity of the Depression in November 1930, when the trusted company failed, creating a quickly-spreading panic in the city's financial community. ${ }^{152}$ Over the next few years, the situation worsened in Louisville. Construction and manufacturing industries' revenues were down along with overall bank deposits. In 1932, the city's unemployment rate reached 23.5 percent for whites and 37.2 percent for blacks while retail sales were down an estimated 60 percent from 1929, the last year of prosperity. ${ }^{153}$

The city's economy was for a while propped up by certain "Depression-proof" industries. ${ }^{154}$ The tobacco industry actually grew during the decade possibly because its products provided much-needed gratification and relaxation. ${ }^{155}$ In the early years of the decade, several of the city's tobacco manufacturers tripled their pre-Depression

\footnotetext{
${ }^{150}$ John E. Kleber, ed., The Encyclopedia of Louisville (Lexington, KY: The University Press of Kentucky, 2001), 296-297.

${ }^{151}$ George H. Yater, Two Hundred Years at the Falls of the Ohio: A History of Louisville and Jefferson County (Louisville: The Heritage Corporations, 1979), 192.

${ }^{152}$ Kleber, 353-354.

${ }^{153}$ Yater, 194.

${ }^{154} \mathrm{Ibid}$.

${ }^{155}$ Kleber, 354.
} 
production of cigarettes. The Brown and Williamson Tobacco Corporation, which had only been in the city since 1929 , provided employment to an average of three thousand workers and produced close to capacity throughout the duration of the Great Depression. Local demand for cheap food and clothing allowed for the Kentucky Macaroni Company and the Enro Shirt Company to continue relatively normal production. ${ }^{156}$ Then with the Volstead Act in December 1933, beer licenses were issued immediately in Louisville, and soon several distilleries opened in the area.

By the mid-1930s, the worst of the Depression era had passed although prosperity had not yet returned to Louisville. While some economic indicators were in an upswing, unemployment remained high. Unfortunately, the tough times for Louisville were not over. On January 6,1937 , rain entered the area that would eventually cause the worst natural disaster the city had ever encountered. By the end of January, Louisville mayor Neville Miller "ordered the evacuation of all residents west of Fifteenth Street."157 The Ohio River finally crested on January 27 at around 51 feet before it "began a slow and grudging retreat." 158 By the end of the emerging Depression, 250,000 residents were impacted, three-fourths of the city had been under flood water, around ninety deaths were attributed to the flood, and $\$ 50$ million worth of property damaged was incurred. Although the river did not return to normal proportions until mid-February, Louisville recovered quickly. The Federal Disaster Loan Corporation loaned over $\$ 1.2$ million to 1,300 homeowners and small businesses. ${ }^{159}$ Louisville would recover from the Great Depression in 1940 when the Census showed some improvement, as unemployment had

\footnotetext{
${ }^{156}$ Yater, 194.

${ }^{157}$ Yater, 200.

${ }^{158}$ Ibid.

${ }^{159}$ Ibid.
} 
dropped to 11.5 percent. In 1937, the Harper's Monthly Magazine printed an article that described Louisville as "an American museum piece" and "the city of let-well-enoughalone."160 The war in Europe, however, would completely turn around the unemployment situation by creating a manpower shortage. The next few years would soon show that Louisville would use the war to reconstruct its economy and emerge from the Great Depression to become the "eighteenth-largest defense supplier in the country."161

No detailed book has yet been written focusing on Louisville during the Second World War, although the wartime experiences have made their way into other works outlining the city's entire history. Other cities, such as Nashville and Montgomery however, have been the subject of work on the changes and continuities during WWII, and these stories help to put Louisville's experiences into perspective. Robert G. Spinney's World War II in Nashville: Transformation of the Homefront (1998) provides an in-depth look at Nashville in the 1930s and 1940s. Spinney notes that when Nashville, a city with the population of 167,402 in 1940 , is compared with towns that experienced a great war boom, it appears that it was not overly affected by WWII. ${ }^{162}$ However, upon closer inspection, Spinney argues "the war brought subtle yet striking changes to Nashville." "63 World War II was responsible for altering Nashville's political culture, especially the local attitude towards government. The new attitude allowed for growth in the public sector which in turn transformed the local political economy. According to Spinney, "the war presented crisis situations that seemed to demand governmental

\footnotetext{
${ }^{160}$ Yater, 205, and Kleber, 956.

${ }^{161}$ Kleber, 954.

162 J. Andriot, 748.

${ }^{163}$ Robert G. Spinney, World War II in Nashville: Transformation of the Homefront (Knoxville: The University of Tennessee Press, 1998), xii.
} 
responses... [such as] soaring juvenile delinquency rates, a venereal disease epidemic, the need for childcare facilities, and an acute housing shortage." ${ }^{164}$ World War II in Nashville differs from other homefront studies in that it examines the changes in Nashville from the late 1930s through the early 1950 s and goes beyond the typical focus on social and economic impact by addressing public sector growth, although it does discuss social and economic issues in brief. While Spinney mainly focuses on public sector growth, his analysis and information on the defense industry, race relations, family life, and public housing provide ample data to compare with Louisville's experiences and statistics. For instance, it becomes obvious that the defense industry itself did much more for Louisville than for Nashville.

Wesley Phillips Newton's Montgomery in the Good War: Portrait of a Southern City, 1939-1946 (2000) provides a case study for another southern city during WWII. Montgomery though was smaller than both Nashville and Louisville with only a population of 78,084 in $1940 .{ }^{165}$ Newton focuses on "the enormous contributions that Montgomery and its people made to war and considers how the war served as a catalyst for future change while also reinforcing many traditional values, beliefs, and experiences."166 He describes the changes in Montgomery as the local citizens witnessed them and follows certain individuals throughout the course of the war. His focus lies more with the people of Montgomery and the city itself than with the governmental changes that Spinney focuses on in Nashville. A lot of the problems that arose in Nashville also appeared in Montgomery such as housing concerns and juvenile

\footnotetext{
${ }^{164}$ Spinney, xiii.

$165 \mathrm{~J}$. Andriot, 748.

${ }^{166}$ Wesley Phillips Newton, Montgomery in the Good War: Portrait of a Southern City, 1939-1946, With an Introduction by Allen Cronenberg_(Tuscaloosa, AL: The University of Alabama Press, 2000), xvii.
} 
delinquency, which again provide basis for comparison to Louisville's issues during wartime.

Spinney and Newton investigate the changes and continuities of mid to large size city life during World War II and are among a small handful of case studies that "examine the profound impact of World War II on southern states and assess their contributions to the war effort." ${ }^{\prime 167}$ Despite their contributions, there is still much work to be done on both northern and southern cities alike. The story of Louisville during war can contribute to this project. Neither Nashville nor Montgomery developed a large defense-related industrial base during the war as Louisville did. The war also profoundly changed the nature of Louisville, particularly through the industrial changes that were sparked by the beginning of the war in Europe. These changes reshaped the character of the city, which led to both positive and negative future developments.

The changes the war in Europe brought to Louisville can only be described as a local "industrial revolution." "168 This industrial revolution revamped Louisville’s economy as the United States prepared itself for war by producing defense materials for itself and its allies. ${ }^{169}$ Even before Pearl Harbor, Louisville was already on a war footing due to defense industry being located in or near the city. The first new war industry in the area was the Indiana Ordnance Works plant in the small town of Charlestown, Indiana, located about 15 miles northeast of Louisville. The plant was owned by the federal government but was operated by E.I. du Pont de Nemours \& Company. ${ }^{170}$ The Indiana Ordnance Works, commonly referred to as the "Powder Plant," manufactured

\footnotetext{
${ }^{167}$ Newton, xvi.

${ }^{168}$ Yater, 206.

${ }^{169}$ Kleber, 954.

${ }^{170}$ Yater, 206.
} 
smokeless powder to be used for artillery purposes. The opening of the facility was announced to the public by mid-July 1940 and was fully operational by May the following year. The powder plant was soon producing close to a million pounds of smokeless powder daily. ${ }^{171}$ Original estimates for employment at the plant, which ranged from 4,000-8,000 including construction workers, were easily surpassed in the first year when "nearly 32,000 workers converged on the site each day." 172 The new plant was certainly an important economic development to Louisville and the surrounding areas, and it also displayed the "American willingness to supply the tools of war to an embattled Britain." 173

By late 1940 other pieces of the industrial expansion were falling into place. The Hoosier Ordnance Works, popularly nicknamed the 'Bag Plant,' was to be built adjacent to the powder plant in Charlestown. ${ }^{174}$ The bag plant was a "bag manufacturing and load, assembly, and pack facility...operated by Goodyear Engineering Co., a subsidiary of the tire and rubber company." $" 175$ The powder manufactured at the powder plant was then sent to the bag plant to be bagged. During the war, construction was started on a third facility in Charlestown to make rocket propellants, but the war ended before it was completed. ${ }^{176}$ Both Hoosiers, from as far away as Madison, Indiana, and Kentuckians, particularly from Louisville, provided manpower to the powder and bag plants.

Around the same time as the Charlestown facilities were constructed, Louisville was also chosen as the site for a naval gun plant. Louisville was a prime spot for the

\footnotetext{
${ }^{171}$ Kleber, 413.

${ }^{172}$ Yater, 207.

${ }^{173}$ Ibid. 206.

${ }^{174} \mathrm{Ibid}$, 207.

${ }^{175}$ Kleber, 413.

${ }^{176}$ Ibid.
} 
plant because "its inland location was less vulnerable to enemy air attacks."177 Construction began on the $\$ 26$ million project on January 29,1941 , on land adjacent to the L\&N's Strawberry Yards in the west part of Louisville. It was officially commissioned as the Naval Ordnance on October 1, 1941. The plant immediately began manufacturing torpedo tubes, gun mounts, and other war-related naval supplies.

Westinghouse Electric Corporation held the contract from the government during the war to carry out the naval production. The Naval Ordnance Plant employed around 4,200 workers during the war's peak production period. ${ }^{178}$ Like the two Charlestown plants, the Naval Ordnance Plant symbolized America's preparedness for war prior to Pearl Harbor.

Still within the same time frame, Louisville received more exciting industrial news. Developments came to the surface in early 1941 that "set the stage to make Louisville the world's largest producer of synthetic rubber," ${ }^{\prime 179}$ which increased in importance by 1942 as Japan took control of ninety-five percent of the world's natural rubber market. In May, the E. I. du Pont de Nemours Company, the same company that ran the Charlestown powder plant, announced that construction would begin immediately on a vast synthetic rubber plant that would have the ability to manufacture 10,000 long tons yearly. The plant was located off Bell's Lane in Louisville's southwestern industrial area and planned on employing 600 workers. ${ }^{180}$ This area was dubbed 'Rubbertown' after the B.F. Goodrich Company and National Synthetic Rubber Company also built facilities near there.

\footnotetext{
${ }^{177}$ Kleber, 648.

${ }^{178} \mathrm{Ibid}$.

${ }^{179}$ Yater, 207.

${ }^{180}$ The Courier Journal, 11 May 1941, Ekstrom Library, Microfilm Collection, University of Louisville.
} 
By 1942, the industrial rubber complex expanded while the "federal government moved to quadruple output by purchasing the plants, expanding them, and then leasing the facilities to the original owners." 181 Louisville's distilleries helped the plants to increase output because of their own wartime conversion to manufacture industrial alcohol, which was a key component to the butadiene used to produce the synthetic rubber. In addition, the federal government had erected a butadiene plant in Rubbertown, which was operated by Carbide \& Carbon Chemical Corporation. ${ }^{182}$ In the peak wartime production year of 1944 , the five Rubbertown factories produced 195,000 tons of synthetic rubber, while costing the government $\$ 92.4$ million and providing jobs for approximately 4,000 local citizens. Thus, Louisville had quickly become the world's leading supplier of synthetic rubber. ${ }^{183}$

Louisville was not only becoming a hub of new war-defense material industries, but well-established local industries also converted their production to defense materials during the war. The Ford Motor Company converted their assembly lines from February 1942 through July 1945 to manufacture military trucks and jeeps, producing close to 100,000 military jeeps. ${ }^{184}$ The company that produced Louisville Slugger Baseball Bats, Hillerich \& Bradsby, shifted production to such items as rifle stocks, carbine stocks, billy clubs, and tank pins, although it still made softball and baseball bats for the armed forces. ${ }^{185}$ The Henry Vogt Machine Company adapted part of its industrial boiler business to the production of ship boilers. At Vogt's peak in 1942, the company shipped

\footnotetext{
${ }^{181}$ Yater, 208.

182 Ibid., 209.

${ }^{183}$ Kleber, 772.

${ }^{184}$ Kleber, 309, and Yater, 210.

${ }^{185}$ Lowell H. Harrison and James C. Klotter, A New History of Kentucky (Lexington, KY: The University Press of Kentucky, 1997), 370, and Kleber, 388.
} 
"one complete boiler a day to the Maritime Commission for use in its vessels.", "Tube Turns Technologies, Inc. focused part of their manufacturing on artillery shells and airplane parts for the war effort. The company produced aluminum cylinder heads for the Pratt-Whitney rotary engine used in military airplanes. ${ }^{187}$ The demands of WWII hardly left a single Louisville industry untouched in some way or another. ${ }^{188}$

The war also affected the local airfields. An eastern extension of Louisville's Bowman Field was transformed into an Army Air Corps training base, where the Glider Combat Training School was installed. The school trained thousands of troops. Because the Air Corp and commercial flights shared Bowman Field, a second air field became necessary. In the fall of 1940, the City-County Air Board purchased 571 acres of land near Preston Street Road and Audubon Park. It was first simply called Municipal Airport Number Two, but within a year was renamed Standiford Field. During the war, a plant was constructed at the new air field to produce mostly wooden cargo planes. Louisville was chosen to host the new industry because both the ideal location of Standiford Field and its established woodworking industry. The federal government constructed the new $\$ 12$ million factory but Curtiss-Wright Corporation operated it. They soon assembled several wooden C-76 Caravans using parts from the local Mengal Company who also manufactured wooden airplane crates and was the first to develop plywood for airplanes. Tragically, "the first of the planes crashed in southern Jefferson County on a test flight in May 1943, killing its three man crew."189 The contract for the C-76 wooden planes, not surprisingly, was cancelled and the plant converted its production to C-46 cargo planes.

\footnotetext{
${ }^{186}$ Kleber, 381.

${ }^{187}$ Ibid., 893.

188 Yater, 210.

${ }^{189}$ Yater, 209, and Kleber 610.
} 
Louisville's American Air Filter Company, which produced hulls for navy ships and army pontoon bridges, contributed parts to the new cargo plane plant, along with Reynold's Metals Company, which was using most of its aluminum for the war effort. ${ }^{190}$ By mid-1941, industrial employment in general had increased 18 percent from the previous year, and local war related defense industries employed 38,000 people. ${ }^{191}$ Thus, Louisville's wartime industrial changes created job opportunities for many new workers. But with so many young men being shipped off for the war effort, more manpower was required on the homefront. Women, both black and white, received new opportunities for employment. During the war, 6.5 million new women entered the workforce across America where they proved themselves capable workers time and again. ${ }^{192}$ Older black men, since the younger men were in the armed forces, received new opportunities to obtain better paying employment. Workers of both sexes and races entered the city from rural communities in Kentucky and Indiana which led to Louisville's population increase of over 50,000 (from 319,077 to 369,129) from 1940 to 1950. ${ }^{193}$ The Courier-Journal noted in early 1942 that Louisville was "the biggest, busiest industrial community it has been in 163 years."194

The industrial changes the war brought to Louisville also influenced other aspects of the city's structure. An influx of people into the city created a wartime housing shortage. When the United States first entered the war, the planning process was underway for two public housing projects, but due to the increase in defense workers, the

\footnotetext{
${ }^{190}$ Yater, 209, and Kleber, 27 and 761.

${ }^{191}$ Yater, 208.

${ }^{192}$ Shirley Mae Harmon, "A Comparison Study of Black and White Women War Workers in Louisville, Kentucky During World War II," (University of Louisville, 1999) 3, and Harrison and Klotter, 371.

${ }^{193}$ D. Andriot, 299.

${ }^{194}$ Yater, 208.
} 
facilities were used instead to house them. It was not until World War II ended that the two projects, Sheppard Square and Parkway Place, were used for actual public housing. Federal low-interest loans paid for the division of old homes into multiple units to provide shelter for most of the war workers. The Federal Housing Administration fully supported this tactic to aid in the war effort. The section of the city referred to as "Old Louisville" was most affected due to "hundreds of large, substantial nineteenth century dwellings in an area that had lost its early claim as the favored residential site of the city's elite, and was well served by the public transit." ${ }^{.95}$ Unfortunately, Old Louisville's "wartime conversion hastened the decline of this area in the heart of the city."196

The war also brought new medical developments to Louisville. Nichols General Hospital was built by the U.S. Army for $\$ 318$ million. It was a 1,000 bed facility located on a 120 acre plot of land at Berry Boulevard and Manslick Road, thus making it the largest hospital in the city. It was a "temporary facility to treat sick and wounded soldiers." 197 The Army also constructed the Louisville Medical Depot south of the city on a 575 acre site next to the L\&N Railroad and Turnpike at the same time as the hospital.

Louisville's social clubs, charity organizations, and community groups were transformed by the war effort as well. The day of the Pearl Harbor attack, Kentucky governor Keen Johnson reassured the president of the United States that the citizens of Kentucky “" [were] ready to follow [his] leadership and make any sacrifice necessary' to meet the Japanese attack on American territory." 198 Within days, Louisville's residents

\footnotetext{
195 Yater, 211.

${ }^{196}$ Yater, 211, and Kleber, 955.

${ }^{197}$ Kleber, 402, and Yater, 208.

198 "Kentucky Is Ready to Sacrifice To Meet Attack, Johnson Says," The Courier Journal, 8 Dec. 1941.
} 
were doing just that. By December 12, 1941, 500 people had registered for defense work with the local Civilian Defense Volunteer Office on top of the 2,000-3,000 applications the organization had received in October.

Louisville's Red Cross chapter also saw an immediate increase in volunteer workers. The Red Cross was in need of a range of women volunteers from their Nurse's Aid Corp to Braille readers and auto mechanics, and was in desperate need of knitters and sewers for their surgical dressings units. ${ }^{199}$ Although volunteerism was high at the onset of the war, the Red Cross had to continue to appeal to local women for their assistance. As the severity of the fighting increased so did the need for surgical dressings. By the end of 1942, the volunteer chairman requested that local Louisville women "give as much assistance as possible" to aid in their task of producing 900,000 surgical dressings by the end of December. The Red Cross appealed for this help by stating, "Your help is needed by a wounded man."200 The organization provided other services to the community such as the Red Cross prisoner-of-war program, which served as "a connecting link between men in the service and their families at home, regardless of where they may be."201 Finally, the program sponsored talks on such subjects as the "means of communication with prisoners and steps which may be taken for their health and welfare."202

Many clubs participated in the war effort such as the Rotary Club, which was involved in such activities as hosting a meeting to kick off the "downtown solicitation in

\footnotetext{
199 "Volunteer Workers of All Classes Answer Call," The Courier Journal, 12 Dec. 1941, and "You Can Find Your Niche in This List of Jobs!" The Courier Journal, 25 Jan., 1942.

200 "Red Cross, Far Under Quota of Dressings, Asks Volunteers," The Courier Journal, 1 Oct., 1944, and "What Women Can Do: Red Cross Calls for Helpers To Make Surgical Dressings," The Courier Journal, 4 Nov., 1942.

201 "Red Cross Speaker to Tell How to Write to Prisoners," The Courier Journal, 1 Oct. 1944. ${ }^{202}$ Ibid.
} 
the Fifth War Loan Drive." ${ }^{203}$ Other clubs were actually started for the war effort such as Health for Victory Club, which was initiated by the Louisville Defense Council and local industrial leaders to "improve the health of war workers and the civilian population."204 The Health for Victory Club, which consisted of women war workers and men war workers' wives, sponsored talks concerning such topics as canning fresh vegetables and fruit. ${ }^{205}$ The Women's Action Committee for Victory and Lasting Peace was created in the middle of the war to "offer to all American women a dynamic and practical program through which they may work together to bring about a just and lasting peace."206 The group sponsored speakers on such topics as how to maintain world peace. ${ }^{207}$

Adults were not the only volunteers for the war effort. Many local children were actively involved in the war effort through clubs, schools, and war-sponsored activities. It was necessary to make children feel important to the war effort so they were often given "tasks fitted to their age and skill." ${ }^{208}$ Louisville's Junior Red Cross, which was a part of the largest youth organization in the world, provided one such outlet for children to aid in the war effort. Junior and senior high school age children participated in the Junior Red Cross through their schools, and it was a priority of the group to enlist every Louisville and Jefferson County child for their efforts. The Junior Red Cross worked on such war-relief tasks as sewing utility bags, constructing games, knitting clothes for the soldiers, recruiting blood donors, and painting, stenciling, and cutting menu covers.

\footnotetext{
203 "Rotary Club Meeting Opens Bond Drive," The Courier Journal, 9 June, 1944.

204 "Nutritionist Addresses Victory Club," The Courier Journal, 6 May, 1943.

${ }^{205} \mathrm{Ibid}$.

206 "Women's Action Group for Peace Organized," The Courier Journal, 11 April, 1945.

${ }^{207}$ Ibid.

208 "Children, Too, Have Place in War Effort," The Courier Journal, 13 May, 1943.
} 
While in school, boys were typically responsible for making metal and wooden industrial art projects for soldiers while girls sewed for them. ${ }^{209}$

Groups such as the Girl and Boy Scouts also turned to civilian defense work. Senior Girl Scouts learned how to repair flashlights, sew buttons, use Morse code, milk cows, make bandages, and use ordinary tools such as scissors, knives, axes, needles, and pliers. They essentially "turned their energies wholeheartedly toward defense." 210 Other students became involved through activities such as poster contests. Students from Theodore Ahrens Trade High School entered and won in a Victory Poster Contest, which chose posters to send to the War Savings Department of the U.S. Treasury to be printed to aid in the sales of bonds and stamps. The local students were awarded with War Bonds and Saving Stamps of their own. ${ }^{211}$

Plenty of social activities were available during the wartime for soldiers. Louisville offered the troops many activities, some involving good clean fun and others more of a mischievous nature. As the big band dance fervor swept through the nation, dine-and-dance establishments became popular with soldiers. The Louisville Service Club opened in March 1941 with the intention of providing servicemen a place to stay on weekend leaves while also offering entertainment. The Service Club was a popular location that brought in nationally known bands. Throughout the war, the club was open twenty four hours a day including weekends and hosted thousands upon thousands of soldiers. The Officers' Club was initiated by the National Society of Colonial Dames "to provide for the underprivileged second lieutenant some of the luxuries hitherto confined

\footnotetext{
209 "40,000 Schoolchildren Make Articles for Soldiers," The Courier Journal, 27 March, 1942, "Junior Red Cross Does a Lot," The Courier Journal Rotary, 19 Nov., 1944, and "Junior Red Cross Girls 'Out for Blood," The Courier Journal, 18 Sept., 1944.

${ }^{210}$ Alleen Christen, "Girl Scouts Are All-Out For Defense," The Courier Journal, 22 Feb., 1942.

211 "10 Ahrens Pupils Are Winners in Poster Contest," The Courier Journal, 29 May, 1943.
} 
to privates and sergeants." ${ }^{212}$ The Officers' Club was open every Sunday in the Rathskellar of the Henry Watterson Hotel for soldiers to dine, dance, relax, play cards, or write letters home. ${ }^{213}$ Other not-so-reputable entertainment for soldiers involved brothels located on S. Seventh Street between Market and Broadway named "the line." Several Jefferson St. bars also hosted gambling opportunities in their back rooms. ${ }^{214}$

Mischief was not only made by wartime soldiers. Some children during the war found themselves unmonitored as their parents were at work or in the service. Juvenile delinquency became a social issue in Louisville, as in other cities across the nation. Nashville, for instance, saw the number of city juvenile court cases increase 43 percent during the early years of the war while school enrollment rates dropped and truancy rates increased seven-fold in a two year period. ${ }^{215}$ Louisvillians believed that juvenile delinquency was increased due to "domestic unrest because of newly increased income and the lure of employment opportunities for mothers who leave children neglected."216 Louisville's public schools experienced an increase in truancy, which officials believed could lead to delinquency. ${ }^{217}$

Various organizations and groups were formed to curb the increased delinquency, including a Crime Prevention Bureau, the Youth Recreation Committee, and the Combined Organization Group. Some groups focused on providing more recreational outlets for Louisville's youth, while others reviewed delinquents prior to their case being sent to Juvenile Court. Apparently, local youths questioned by the police for being in

\footnotetext{
212 "Something for the Boys with Bars," The Courier Journal, 30 April, 1944.

213 "Something for the Boys with Bars."

${ }^{214}$ Kleber, 571-572, 956.

${ }^{215}$ Spinney, 82.

${ }^{216}$ Tarleton Collier, "Social Workers Plan to Curb Delinquency," The Courier Journal, 5 May 1942.

${ }^{217}$ Collier.
} 
"local hot spots where liquor is sold" repeatedly asked the question "Where are we supposed to go?"218 And they had a point. There were not many places for them to go. Police Lieutenant William Kiefer, superintendent of the Crime Prevention Bureau, stated, "Wholesome recreation is an absolute necessity for children and the parent who doesn't recognize this is being dangerously shortsighted." ${ }^{219}$ One such suggestion to keep delinquents busy was to "work the hell out of "em." ${ }^{220}$ At one point it was suggested that tough Louisville youths could be transformed into farmhands for seasonal work. ${ }^{221}$

Clearly the war brought many changes to the city of Louisville and affected all aspects of society. WWII brought Louisville out of its economic slump which helped to rejuvenate the city. Although Louisville was not without its share of problems during the war, the war brought many positive changes that remained in place once the war ended. Much of the defense industry that came to Louisville easily converted to regular production while many established industries that switched over for the war effort easily reconverted. For instance, "synthetic rubber had become a staple of the American economy and Louisville retained its rank as the largest center of American production."222 The plant operated by the Curtiss-Wright Corporation was purchased in 1947 by the International Harvester Company to produce tractors, while Reynolds Metals expanded their local operations due to their foresight about the post-war demand for aluminum products. ${ }^{223}$ Many other industries went through the same process which allowed Louisville to remain a booming industrial center.

\footnotetext{
${ }^{218}$ Marion Porter, “"Where Are WE Supposed to Go," The Courier Journal, 15 March 1944.

219 Porter.

${ }^{220}$ Edna Carroll, "Work on Farm Prescribed To Solve Juvenile Problem," The Courier Journal, 23 April 1944.

${ }^{221}$ Carroll.

${ }^{222}$ Yater, 214.

${ }^{223}$ Yater, 214.
} 
Many of the social changes WWII brought to Louisville remained intact as well. Clubs such as the USO continued functioning and even expanded although the number of soldiers passing through declined. The Rotary, Girl Scouts, and Red Cross did not disband when the war ended but simply went back to their normal routines within the community. New commercial projects began, which included such goals as new space for the WHAS radio station. The popular Stewart's department store outlined a sevenstory addition. The actual population of the city increased by 15.6 percent in the war and post-war era, despite the new trend that demonstrated a shift in living from the urban core to the urban fringe. Overall, the war helped rejuvenate both Madison and Louisville, but Madison kept its small community nature after the war while Louisville expanded into a large industrial city. 


\section{CHAPTER 3}

\section{WAR INDUSTRY AND SIZE}

The industrial changes brought to the cities of Louisville and Madison certainly affected the nature of the towns themselves, albeit differently. The war brought large amounts of new industry to Louisville while many established industries converted to wartime production. This industrial boom pulled Louisville out of the Great Depression while stabilizing and then pumping the economy. Most of the industries made an easy conversion back to civilian production once the war ended which left the city in a strong industrial and economic state.

Madison, on the other hand, shared some similarities with Louisville as far as industry goes, but post-war differences also occurred. Several major local industries converted to wartime production and easily reconverted after the war. The major war industry that came to town, the Jefferson Proving Ground, remained, but it scaled back in size and did not employ the same number of people as it had during WWII until the Korean War began. Although the war did pull Madison out of the Depression, particularly with the employment at the JPG, it did not become a thriving industrial city like Louisville. It retained its small town characteristics.

The amount of industry each location had during the war was relevant to the size of the town which meant that many workers in both locations took a war job or had a family member who did. Thus, most families in Louisville and Madison contributed 
industrially to the war effort. Both cities were similarly affected by industry during the war. Louisville and Madison workers, being only 50 miles apart in distance, also converged to work in war industries in the other city. For instance, the JPG hired construction crews from Louisville while their facilities were being built. Also, with the Charlestown Powder Plant and Bag Plant being located 15 miles outside of Louisville and 35 miles from Madison, people from both cities were employed at those facilities.

Industry, whether wartime or otherwise, is not typically thought of as affecting the lives of young children. But parents or other family members' jobs, particularly during a national crisis such as war, can certainly have an impact. During WWII, many women entered the workforce and were forced to find other care for their children with relatives or neighbors or leave them at home by themselves if they were of an appropriate age. Although the phrase "latchkey children" had been around for well over a century, it became popular during WWII as these children became a social concern. Children running around unsupervised or away from a watchful eye caused an increase in juvenile delinquency. This became a well-known problem during the war with many social groups, churches, and schools analyzing and offering advice on how to curb the delinquency. For instance a book published in 1942 entitled You, Your Children, and War stated,

Many delinquent adolescents are children who are striking out to prove that they can get the best of others; to prove that they themselves are big and strong. To prove that they can defeat in order to escape being defeated. They are searching for a kind of invulnerability for themselves. When their histories are investigated and their inner feelings are made known, they are shown to have felt unloved and deeply resentful of the lack of love. ${ }^{224}$

\footnotetext{
${ }^{224}$ Dorothy W. Baruch, You, Your Children, and War, (New York: D. Appleton-Century Company, Inc., 1942), 204.
} 
Some wartime factories even offered child care but they were few and far between. The Lanham Act, which President Roosevelt signed into law in 1940, was supposed to provide funding for the various needs of communities in war-boom areas. One such designated need was that of child day care centers, but these centers were not set up quickly due to critics of the program and the lack of facilities and staff to work at the centers. Only 58,682 children were being taken care of by Lanham day care facilities in the entire country by the end of $1943 .^{225}$

Although child care centers were not abundant, the media often embellished the stories of neglected latchkey children. There were a few true stories of children locked in their mothers' car while the mothers went to work, being dropped off at all-night movies alone, or even being chained to trailers, as occurred in one California trailer park. There were also increased incidences of runaways and other truant behavior, some as extreme as prostitution, but it is inaccurate to describe this behavior as the norm, as many journalists often did. It has not been proven that the majority of latchkey children were neglected by their working parents. ${ }^{226}$ Rather, many children were given more responsibilities at a younger age due to the necessity forced upon them. These new responsibilities were often understood but were not always liked by all children. Mary May Morris, a young girl from Connersville, Indiana, saw her homemaker mother take a job during WWII in a butterfly bomb factory, while her brothers were away at war. Morris referred to the time her mother worked as "the worst time of her life" because her mother was not home as much and was a nervous wreck when she was. ${ }^{227}$

\footnotetext{
${ }^{225}$ Harmon, 64.

${ }^{226}$ Tuttle, 72, and Steven Mintz, Huck's Raft: A History of American Childhood, (Cambridge, MA: The Belknap Press of Harvard University Press, 2004), 259.

${ }^{227}$ Mary May Morris, interview by author, 9 April 2006, Morristown, Indiana, tape recording.
} 
Parents and children in Louisville and Madison faced some of these national problems during the war. However, of the six women interviewed, none had serious runins with juvenile delinquency or child care issues despite the fact that one or both of their parents worked. War industry instead altered various parts of their lives such as their daily routines, financial well-being, and home life. The effects of this war work were the same on the girls regardless of type of industry, location, and size of community.

Five of the six girls had close relatives who took similar war jobs, which disrupted the girls' lives in some form or another and in the least brought a change in employment to their families. All three Madison girls had at least one parent take a war job, and two girls also had siblings employed in a war industry. During the war, Bear's father worked as a guard at the Charlestown Powder Plant, while McCauley's father was a fireman and guard at the Jefferson Proving Ground. Jones's father was a full-time farmer but also took a job at the JPG during its construction phase. Bear and Jones's older sisters were also employed at the JPG while their significant others were overseas. McCauley's mother left her office job in downtown Madison to work at the JPG as a secretary and stenographer before moving on to other proving ground sites across the nation to do war work. Clearly, the addition of employment due to the Jefferson Proving Ground affected many local lives.

Two of the Louisville girls had mothers who took war jobs at the Charlestown Bag Plant as sewing machine operators. Neither mother had worked outside the home since they had been married. Both the girls' fathers worked in industries that converted to the war effort, but the girls were unsure if their fathers' positions changed for the war effort. It did not matter that the girls lived in cities of different sizes with different types 
of war industry. The types of jobs their family members took were similar, especially since many worked at the related plants in Charlestown. The war industry that came to Louisville, Madison, and the surrounding area provided new jobs for those who wanted them.

One way that the war industry altered the girls' lives was that it disrupted their normal daily routines in various fashions, some big and some small. These changes were similar regardless of where the parent worked and where they were from. Mary Jane Bear's father was the manager of several chain grocery stores in Madison prior to the war but left his position at Kroger's to take a war industry job at the Charlestown Powder Plant in Charlestown, Indiana. Bear's father became a guard at the plant and eventually was contacted by the federal secret service to become an agent, although Bear herself was unaware of his position with the government until the 1970s and unsure of how and why her father was chosen for such a position. Bear's mother did not work prior to the war or during the war, so her father was the sole breadwinner of the family. When he switched from grocery store work to security guard during the war, he sometimes had to work the night shift. Bear said they had a sign hanging in their window that stated, "War Worker Sleeping" which meant that everyone should be quiet. It was a signal for visitors to avoid using the doorbell and to knock softly. Bear declared, "They deserved that."

Marian Brennan's father switched shifts as well during the war to the night shift at American Standard, while his wife worked the day shift at the Charlestown Bag Plant. Since Brennan's father was on the swing shift during the war, which was from 3 p.m. to 11 p.m., Brennan only saw her father when she came home from school for her midday meal. Her middle school, St. Benedict's, did not have a cafeteria, so the children were 
given permission to walk home for lunch. Her father was then responsible for feeding her before he went to work. She stated, "I would walk home and always eat with Dad for lunch...My father would cook. He's the one I picked up cooking from when I was in the $5^{\text {th }}$ and $6^{\text {th }}$ grade on up during the war." Her father had always liked to cook even though her mother was usually in charge of such duties. Brennan's father would usually make her meals of baked chicken, fried chicken, roast, or soup. Her parents grew a Victory Garden during the war, so her father would also cook fresh green beans and other items from the garden. Brennan declared, "Oh, he'd make a meal!" Since her father did not get off work until she was already in bed, lunchtime was the only time she could really spend with him.

Throughout the war, since Brennan's mother did not get off work until midafternoon, if she did not have to pull overtime shifts at the Bag Plant, she was not always up to the task of cooking dinner after a long tedious day at work. She had a lengthy commute back to the West End of Louisville from Charlestown, so she would sometimes call Brennan ahead of time to meet her for dinner at the local restaurant The Blue Boar on Walnut St. between $4^{\text {th }}$ and $5^{\text {th }}$ Avenues. Brennan, who was in the $7^{\text {th }}$ grade at the time, would walk down to the corner and catch a bus downtown. Her mother instructed her to wait at the restaurant until she arrived and said, "Now you wait there until I come...Don't you talk to anybody, and if anybody talks to you or says anything to you, you just say 'My mother will be here in about 10 minutes,"' and that's exactly what Brennan did. She got used to traveling by herself during the war, although it was not often that Brennan would travel out of her own neighborhood in the West End. 
Steven Mintz, author of Huck's Raft: A History of American Childhood, acknowledges that being a young child amidst a country at war meant experiencing "disruptions and stress, but also early opportunities to contribute to the family and assert one's independence." 228 Brennan is a prime example of a young girl whose daily routine was altered by her parents' work during the war. Because of her parents' employment, she had added responsibilities that she would not otherwise have had as a young girl. Several of the other girls shared similar experiences. Unlike the reported juvenile delinquents, none of the girls whose mothers took war jobs got into out-of-the-ordinary trouble. Ann St. Clair's mother worked at the Bag Plant in Charlestown, like Brennan's mother did, so she was often on her own while her mother was at work. She did not particularly get into any trouble and was fine with her mother's temporary absence. She stated, "I just ran the streets and played Kick the Can, roller skated, and played Hopscotch."

McCauley is the only Madison girl whose mother took a war job outside of the home. However, since she was living mainly with her grandparents at the time, she was not left to run around on her own. Her grandparents were very strict about where she could go and much of her childhood was relegated to playing in the back yard with cousins. Her mother taking a war job did not really affect her as much because she said, "She always worked...I was just used to Mother working." Her mother did leave Madison during the war and traveled with an engineering group to work on various proving grounds and war housing developments. McCauley remained with her grandparents until she graduated from high school after the war had ended.

${ }^{228}$ Mintz, 258. 
Brennan felt the added responsibilities she had when her mother went to work, but she knew it was unacceptable to disobey her parents. Brennan learned that she had to be more responsible for her actions because there were times when her parents were not at home. She declared, "I had rules...Children now get in trouble and they say, 'Oh, well their mother worked.' Well, my mother worked, but I wasn't allowed to get into trouble. I'd imagine I'd hear about it if I did." Brennan did not mind the extra time she had at home by herself, and she would do her homework and read until her mother got home. She stated, "I'd sit down and do my homework, and that's what I would do until she got home from work. So, I was really by myself like a couple hours, but I never was afraid...I was told to do that, and that's what I did." Brennan also felt comfortable at home by herself because she had her old dog Queenie there with her. Queenie would get up and growl when anyone would come near her house, even the mailman, so this gave Brennan peace of mind while she was at home alone.

Brennan's responsibilities while her mother worked often entailed running errands for her parents. If her mother was late in coming home from the Bag Plant, Brennan was often in charge of depositing her paycheck. Her mother would instruct her to put the paycheck in her purse, ask a neighbor to walk with her to the bank a few blocks away, and then deposit the check. The bank would give her the receipt and she would return home. Brennan said,

I learned how to do banking. I learned how to travel on my own [even though] usually when I went out I went out with someone... So I think I learned more responsibility during the war. I believe all children in that age had to really grow up a lot. We couldn't say, 'Well, I have to wait and let my mother do it,' because my mother might not have time to do it. 
The Madison girls did not have as much a burden of extra responsibilities since both Bear's and Jones's mothers were at home and McCauley had her grandparents around. However, Jones's mother had to shoulder extra responsibilities around the farm once her sons went off to war and were no longer there to help. Jones had her regular chores such as setting the table and gathering the eggs, but she had some added responsibilities during the war too like helping with the harvest of the tobacco. She was not old enough to do some of the jobs her mother had to take-on, but she could help with the tobacco. She was not fond of the job and stated, "I didn't like it at all because it stinks and it's sticky, and they always had a sucker where the leaves came in. If you topped it, then these little suckers would come out of each leaf. My dad would have to take those off, and I would help do that, and oh I hated that job."

The war jobs the girls' family members took helped the family out financially while also providing support to the country in the war. The mothers with sons in the service took the job mainly to keep their sanity and to avoid worrying while their sons were gone. McCauley believed that her mother "felt that she was really doing the best she could and supporting her brother who was in the service." Patriotism was at least part of her motivation. Jones's father worked at the JPG during its construction phase which was prior the US entrance into the war, and his motive was more financial at the time, but Jones believes patriotism may also have been a factor in his case. He was a full-time farmer, but the Depression had been hard on his family. Jones stated, "We didn't have a lot of money during that time at all. During the Depression they were really hard up. He only worked there I think for a short time when they were building it. It was extra money. It wasn't the type of thing that he was there throughout." 
Brennan and St. Clair's mothers both took war jobs to help keep their minds off their sons fighting in the war, although during the war the St. Clair family was finally able to purchase their own home in the West End of Louisville, so financially it may have helped too. Shirley Harmon's comparative study of black and white women war workers in Louisville validates the reasons Brennan and St. Clair's mothers sought employment during the war. Harmon discovered that white women war workers had "a sense of patriotic duty although they...were working for economic reasons as well.,"229 St. Clair's mother had not worked prior to war, but she stated, "For one thing, I think [she took the job] to get her mind off of my brother because she never was a worker outside...I guess she thought it was great because it took her mind off of everything." Brennan's father at first did not want her mother to work during the war since Brennan was still in grade school. She had worked previously as a telephone operator before she was married but had to quit after they got married. Brennan remembered her parents discussing her working at the Bag Plant and specifically her mother stating,

Well, I want to go to work because when Marian's at school and you're working, I'm here by myself...I don't think I can take it. I believe I'll have a nervous breakdown or something will happen to me if I don't get my mind on something. If I go over there and start sewing those bags or whatever they want me to sew, I feel like I'm helping my sons...Somehow or 'nother I'm helping 'em.

The girls' family members had similar motivations for working regardless of living in Madison or Louisville. The jobs their family members took affected the girls' daily routines, views on war work, and responsibilities regardless of the fact that the jobs were in different cities. The fact that Louisville had more war industry during WWII did not affect the girls and their families. The amount of industry located in Madison was

${ }^{229}$ Harmon, 46. 
relevant to the size of the community. In addition, many of the residents of both towns were driving to Charlestown to work, so Louisville and Madison shared that employment opportunity. Thus, both cities were affected similarly by the war industry during WWII, although the post-war is a different story, and the girls and their family members who worked in those industries were also similarly affected. 


\section{CHAPTER 4}

\section{COMMUNITY, CHILDHOOD ACTIVITIES, PROPAGANDA, AND WWII}

Thus far, it has been shown that Madison and Louisville underwent similar social and industrial changes during the war despite the difference in size of their communities and in enduring post-war impact. The industrial changes affected the six girls at the heart of this study in the same manner regardless of growing up in either city. Similarly, the size of their respective communities did not affect opportunities for entertainment and the types of propaganda the girls were involved in and subjected to. This is because the girls, although generally aware of the size of their overall city and the differences between rural and urban settings, still experienced their immediate neighborhood of the larger city as a small-town community. The Louisville girls did not particularly experience Louisville as a large city because of their age and social class, which limited their mobility and means to do certain big city activities. Madison, although it was a small community, was still split between the West End and the East End, and not much mixing occurred, again because of age and mobility.

The Louisville girls' awareness that they lived in a big city were shaped by time spent in smaller "country towns," and the fact that Louisville was separated into various internal communities, i.e. the West End, the End End, Downtown, etc. Ann St. Clair spent part of her childhood in the country in Washington County, Kentucky before 
moving permanently to Louisville. As a child, she viewed the difference between the country and the city in terms of food products. She stated,

I remember us being country kids and we came to town, and down here they had the big fresh donuts. Out there they didn't. It was just little country stores. They didn't keep that kind of stuff. They had chocolate milk, which we didn't have chocolate milk. Our cows wasn't chocolate! They was just plain cows!

She also saw a difference in the types of materials used for clothing. When they lived in the country, her mother made underclothes out of feed sacks, which many of the girls in Madison also remember doing. St. Clair's mother said when she moved to Louisville that she was not going to have her children in the feed sack cloth when they had silk ones in the city. She said her mother caught up pretty fast.

Rosemary Block was removed from the city during the Flood of 1937 to Hopkinsville, KY, which was on the Kentucky-Tennessee border. She remembered the local residents of Hopkinsville talking about how big Louisville was, so she thought it was a large town. Marian Brennan did not travel much out of the county but realized how large Louisville was when her mother would talk about the East End, which was not close to her residence in the West End. She remembered riding the street car up and down Broadway, which seemed quite a distance to her at a young age. All three girls had some mobility through town via the street car, but as will be demonstrated, their "home base" which was their individual neighborhood, was seen, perhaps unconsciously, as a small town community.

The Madison girls were aware that they lived in a smaller community but still that community was broken down even further to the West End, East End, and North Madison. Mary Jane Bear did not remember realizing that Madison was small on her 
own, but she did know that she had aunts who lived in the big city of Indianapolis and that it was a treat to go shopping in downtown Louisville. Nancy Jones' view was similar to Bear's. She realized the difference in size when she would occasionally go to Louisville with her mother for a doctor's appointment or shopping. She said, "I always loved to go to the big city because Madison was pretty small." She also was aware of the urban/rural differences. As a young girl growing up on a farm, especially when she became school-aged, she felt isolated and wanted to be where she could see her friends more because she believed they had more fun: "You are kind of stuck when you live on a farm," she said. "Consequently, I never wanted to live on a farm."

McCauley had similar experiences with size and urban/rural differences. She understood that Madison was a smaller town because she was aware of the general size of Louisville and Indianapolis. Her first big trip out of town was to visit some of her father's relatives in the city of Indianapolis. She also experienced farm life because she visited her step-grandmother who lived on a farm close to Indianapolis. Even though McCauley lived in a smaller town, she was unprepared for farm life. She stated, "I remember getting up in the morning and helping her pick green beans for dinner that day, which was something. I was a town kid, and I didn't know how to do that." Despite the fact McCauley lived in a smaller community surrounded by farm land, she lived in town and had no farm experience.

Although the Louisville girls were aware they lived in a big city, they did not particularly experience it as such due to their age and mobility. Both Block and Brennan grew up in the West End, while St. Clair lived more downtown before moving to the West End during WWII. Historically, residents of Louisville have "demonstrated a 
strong sense of neighborhood identity.",230 The West End was generally defined as the neighborhoods and industrial section west of the downtown commercial business district. It was enclosed by the Ohio River to the north and west sides. The neighborhoods consisted of mostly white working class families but pockets of black population were interspersed within the area. This side of town was isolated to some extent by the border of the Ohio River and the roads and railroads that divided it into various sections. The girls experienced their own neighborhoods as their main communities because almost everything they were involved in was located within these areas. For instance, they went to school, church, and the movies all within blocks of where they lived. They also played only with children in their immediate neighborhoods. All three Louisville girls walked to school and church. Until they were in high school, they socialized only with the other children in their neighborhood. For instance, Brennan walked to St. Benedict's Elementary School with two girl friends that lived near her and usually played with the Baries children who lived around the corner. Mrs. Baries would often take the neighborhood children to the park for picnics or walk them down to the fairs that would come to town. Several large city-owned parks, such as Shawnee Park, were located in the area. Block usually played with the girls in her neighborhood, many of which were different ages. She said, "Most the time the older girls had to take care of some of the younger boys and girls, you know, so they could play too." She had some other girl friends in her class in school but they lived on the east side of the school, which was about 10 blocks away, so they did not mingle much outside of school. St. Clair had the same experience as Block and Brennan. Her friends were the children who lived in her neighborhood. The girls would occasionally travel out of their neighborhoods to do other

${ }^{230}$ Kleber, 649. 
things, just as the Madison girls did, but their base remained within this smaller neighborhood in a certain section of Louisville, i.e. the West End.

Although Madison was much smaller, the girls there had the same types of boundaries. Children from the West End did not know those kids from the East End even though Madison was itself a small community. Children in the West End went to Lydia Middleton Elementary School; those in the East End attended Eggleston Elementary School, and the Catholic children attended one of the two parochial schools. Those who lived in the country, such as Jones, went to North Madison Elementary. Bear stated, "I had friends mostly in the west part of town. It was sort of divided into East [End] and West End, and so as a child before I went to junior high, which was the seventh grade at that point, most of my friends were in the West End of town where I lived." Both Bear and McCauley grew up in the West End and later in life married men who also grew up in Madison. However, they did not meet their husbands until junior high or high school, because they grew up in the East End. Even though Jones just lived a few miles outside of town, she did not know many people outside of her rural neighborhood, school, or church group, until the North Madison schools consolidated with the Madison schools.

Saturday nights were when all the Madison community members would converge on the downtown area to get their weekly shopping and visiting done. McCauley stated, "Everybody walked uptown. We met people...We lived in the West End of town, so we met relatives from the East End of town, you know, and visited...That was the time to visit, get groceries, and whatever else was needed." Bear remembered doing the same on Saturday nights: "I remember the Saturday night shopping. All the stores were open on Saturday nights, and we always went uptown...The streets were full of walkers and 
visitors, and we would park on Main St. and get a sack of candy in the dime store and that was the highlight of our week." Jones's family would do the same. She recalled her mother always having a list of the items they would need for the following week. They would go to the various stores in which Jones loved to browse. However, her biggest excitement about downtown was ice cream. "I always wanted to get an ice cream cone. That was the thing I wanted when I went to town," she recalled.

Most of the girls from both cities were aware on some level of their social class as well, which was at the time determined by their father's employment, though it did not matter much to them. Five of the six girls belonged to what could be described as working class families, and one more accurately belonged to the middle class. The fact the girls were all in the working to middle class is one reason why I believe the war affected them in similar ways regardless of size of community. Of the Madison girls, Bear's father was a manager for different grocery stores before taking a job at the Charlestown Powder Plant as a guard, and her mother did not work. Jones's father was a farmer but did work a part-time job at the Jefferson Proving Ground during its original construction phase. McCauley lived with her grandparents for the majority of her childhood, so her situation was a bit more unique. Her grandfather worked at a tack factory in town, while her mother was employed in office work before taking a war job at the JPG and then traveling around the country performing war work. McCauley's father was a delivery person at a local grocery store owned by relatives until he became a fireman at the JPG. In Louisville, Brennan's father worked at the American Standard Plant before and after the war. Block's father changed jobs shortly before the war and 
was employed at a brewery. St. Clair's father switched jobs between Jeffboat and the Ford Plant. When laid off at one place, he would attempt to find work at the other.

Brennan remembers thinking that if she saw a dollar bill, she thought she was rich. She remembered that, as a child, she never really thought about status. She said, "We never really did think about it. I guess "cause we never did know anybody [that was rich]. We just accepted what we had, you know." She did remember once being aware of class or social status. Brennan had an aunt and uncle that were well-off and lived in a beautiful two story house at $7^{\text {th }}$ and Breckinridge. She visited them with her father growing up. She stated,

I noticed the difference there. When I went there, they had hard-real pretty hard wood floors, which we didn't have when we lived on Kentucky St. I had to be very careful when I went there, because my aunt was real strict...I had to wear my Sunday dress and my patent leather shoes. I didn't care too much about going there because I'd be there a little bit, for a little while. I [would] get a little restless. I had to get up and walk or else go to the bathroom, and my aunt when I'd get up to walk, she was always afraid I'd scratch the floors...I didn't like to go visit them, but I had to go with my father every now and then...So, I don't like hard wood floors! But I don't know why I would scratch them because you just walk on them!

Block and St. Clair were aware of their class to the same extent Brennan was.

Block knew her family did not have a lot of money and remembered times when either her sister or she would need something but had to wait until the family could afford it. She and St. Clair felt like most the people in their neighborhoods were in the same boat however. St. Clair said, "We was in like two room apartments, and I guess there was some of them that had better homes maybe that rented out their upstairs...But most of us 
was just country people that moved down that didn't know too much of anything." ${ }^{231}$ For the most part, the Madison girls were aware of their social status in the same type of way as the Louisville girls. McCauley stated that she knew her family was poor and did not belong to the same class as the doctors or lawyers but she always felt well provided for. Jones also knew her family had been particularly hard hit during the Depression and that they did not have much extra money.

Because of their age group and social status, the girls of both locations did not participate in war-influenced activities that might be available only in big cities. United Service Organization (USO) dances or Officers' Club parties were an example of this. Both Madison and Louisville had similar organizations but Louisville certainly had more foot traffic of uniformed men and opportunities for local girls to participate in activities involving hosting soldiers. However, because the girls were too young to participate in this kind of social event, the size of their communities does not appear to be a factor. And because they all belonged to the middle to working classes, they would not be spending money doing other wartime activities that were expensive if they were of the proper age.

The young girls growing up in Louisville and Madison were involved in the same type of childhood activities before the war and during the war due to their age group and social status and not because of the size of their communities. The activities they participated in were therefore similarly affected by the changes war brought. Before the war, the girls from both locations were playing such games as Hide and Go Seek, jump

\footnotetext{
${ }^{231}$ St. Clair's family had more recently moved to the city of Louisville and much of her family was still located in Washington Co., Kentucky. Block's and Brennan's family had resided in the city for quite some time, and each had at least one parent born in Louisville.
} 
rope, baseball, dolls, Kick the Can, marbles, and other very typical childhood activities. There was not much difference in their childhood games.

The main source of entertainment for all the girls was the movie theater. This is a prime example of entertainment that was modified during the war years but did not vary by city. Even before America entered the war, Hollywood was already producing movies with a war theme. Roosevelt himself stated that he wanted no censorship of motion pictures. After Pearl Harbor, various studios rushed to copyright titles involving Pearl Harbor, Hawaii, and the Japanese, although they were not immediately produced. Soon though the movie production industry began working with the government to comply with government requests concerning war films and even producing films for them to "serve the war effort.,"232 During WWII, "movie attendance skyrocketed." ${ }^{, 233}$ Hollywood was responsible for releasing 1500 movies, 25 percent of which consisted of combat pictures. However, Americans eventually grew weary of war films so Hollywood also produced Westerns, musicals, and comedies. ${ }^{234}$ These types of movies often appealed to young children.

All six of the girls enjoyed going to the movies before and during the war. Most of the girls considered this their main source of entertainment and saw similar type of motion pictures. St. Clair stated, "It was my only recreation I feel like I had." She went so far as to save part of her lunch money to be able to go to the movies more often. McCauley stated in a similar fashion, "We went probably once a week. That was mostly our entertainment." Bear's and Brennan's fathers both loved the movies so that aided in

\footnotetext{
${ }^{232}$ Richard Lingeman, Don't You Know There's a War On?: The American Home Front, 1941-1945, (New York: Thunder's Mouth Press, 2003), 171.

${ }^{233}$ Tuttle, 154.

${ }^{234}$ Ibid.
} 
their being able to attend on a regular basis. Bear stated, "My father loved the movies and so did we, so we went to the movie, as a family, every time it changed." Brennan's mother was not particularly fond of the movies, but her father was, so he would always take Brennan to see the Shirley Temple and Sonja Henie movies. Block would usually go to the movies on Sundays when she was a young girl. She recalled seeing a lot of Westerns which she was not very fond of but said "That was what I had the money to go see, and it was better than staying at home." Jones did not go as often as the other girls, since she lived out on a farm, but she does remember certain movies of the wartime era such as Mrs. Miniver and A Guy Named Joe that left a lasting impression on her.

Like Jones, the other girls saw some wartime films, but since they were still children also saw movies of other varieties. When they were younger they mostly enjoyed the animal movies like Lassie and Flicka, the cartoon shorts, musicals, and comedies starring Abbott and Costello or Laurel and Hardy. As they entered their teen years, they enjoyed some of the war romance movies or adventure movies.

Madison had two movie theaters during the war years, and Louisville had well over a dozen. However, the number of movie theaters made no difference to the Louisville girls and their choice of movies. They rarely went to the big theaters downtown but went instead to the local neighborhood movie theater. Block was unable to recall the name of the theater in her childhood neighborhood but knew she did not go to other parts of the city to see movies. She said, "Those [theaters] were downtown. Those were the big ones. I went to a neighborhood one. It was at $18^{\text {th }}$ and Oak." Brennan recalled going to the Parkland Picture Show which was located around $28^{\text {th }}$ and Dumesnil. The fact that Louisville was a larger community and offered more movie 
theaters was not a major factor in the Louisville girls' lives since they mainly went to their neighborhood theaters anyhow.

As the United States entered the war, children all across the country found themselves eager to participate in the war effort. The 1942 You, Your Children, and War, which was a book instructing parents on how to deal with their children and morale on the homefront during WWII, stated, "Children want to know that they can be of some use in the war. Even the youngest enjoy spasmodic bits of helping. Whereas those in the middle years and early adolescence attain an augmented sense of their own worth when they have 'joined up' to contribute their share." ${ }^{235}$ Morris, from Connersville, Indiana, recalled collecting balls of tin foil and writing to servicemen to participate in the war effort. ${ }^{236}$ June McCormack Moon, who was born in 1929 and grew up in Hampton, New Jersey, was a member of the Girl Scouts. She stated, "We would roll bandages almost every meeting for the boys. We knew where they would be going." 237

Children's extracurricular social groups, clubs, and games were often transformed to benefit the war effort. The Madison and Louisville girls experienced the same types of transformation due to the war, if they felt their activities changed at all, regardless of their community, although the girls were not necessarily all in the same types of clubs and activities. For instance, Bear and Jones were both involved in the Girls Scouts during the war, but it just so happens that none of the Louisville girls were involved with the Girl Scout organization although many young children in Louisville were at the time. The girls still participated in the war effort in similar ways. Bear volunteered her time with

\footnotetext{
${ }^{235}$ Baruch, 146.

${ }^{236}$ Morris.

${ }^{237}$ June McCormack Moon, interview with Eliza Davino and Sandra Stewart Holyoak, 20 Oct. 2003,New Brunswick History Department, Rutgers Oral History Archives.
} 
the Girl Scouts knitting squares that were sewn into blankets for military hospitals, rolling bandages, and writing to servicemen. Jones was a Girl Scout towards the end of the war but remembered helping her mother roll bandages through her Ladies Aid church group. Both girls also recall saving various materials to help the war effort such as tin foil off gum wrappers and string. Bear recalled,

One of my favorite candies were Hershey's Kisses, and they used to be wrapped in tin foil but between the tin foil and chocolate was a very thin layer of almost like tissue paper... and the same with chewing gum. There was a layer there of thin paper, and you would roll that paper off and then wad the tin foil up into a ball.

Although not in a formal group, Block also contributed to the war effort. She stated, "[I was involved] in just what all the kids in the neighborhood were involved in-saving everything! Everything, tin foil, and old bike tires or any parts of tires, parts of metal we could find, [and] string." She and three or four of her friends would scourge the neighborhood looking for excess materials to place in their wagon. Then someone would come pick it up from them to take to the proper receptacles. Brennan, St. Clair, and McCauley did not recall participating in the war effort in these particular ways. Again the size of community did not affect the girls who participated in the war effort nor did it the ones who did not or could not recall participating.

Propaganda and the media was another influential factor on children during the Second World War. These modes included comics, newspapers, books, magazines, radio programs, movies, posters, billboards, and cartoons. The media sent mixed messages that enforced patriotism, prejudice, racism, tolerance, pride, violence, support, and even fear. Clearly many of these messages were contradictory, but they were out there for young eyes and ears to see and hear. Sometimes the propaganda urged young people to become 
very loyal and patriotic to their country especially through such songs often heard on the radio such as "God Bless America." Sometimes, too, children were taught to hate the enemy at a very young age. ${ }^{238}$

The question arises again if the size of Louisville and Madison affected the girls' reception of and exposure to propaganda messages. Were girls from the bigger city more exposed to various modes of propaganda or were the girls from Madison imbued with particular views from their community? The girls all shared similar memories of war propaganda and news, while none remember being particularly targeted through children's campaigns. All the girls shared similar views on America's enemies and shared the same general concepts of the location of the war. Therefore, the size of the community did not affect young girls lives concerning propaganda, war news, views on the enemies, or understanding of the war's location in this case study. Rather, age probably played the main role here.

Most of the girls remembered seeing and hearing Rosie the Riveter propaganda, mainly through the song with the same title. St. Clair vividly remembered it as she broke out into song. Block, a little more subtly, stated, "That was a big song." Bear recalled the following anecdote concerning Rosie the Riveter propaganda:

I remember there was a movie actress named Veronica Lake...As most women wanted to do, they wanted to copy movie stars, and she had a hair style where the wave came down over one eye, and for the safety of the women that did go to work in the factories...Veronica Lake changed her hairstyle because that was a problem, safety problem with women's hair in their face. So, she changed her hairstyle and encouraged other women to do that.

The girls also recalled seeing many Uncle Sam images. McCauley remembered seeing an army poster, perhaps in the post office, that had a picture with him stating, "We Want

${ }^{238}$ Tuttle, 243-245. 
You!" The same types of images were seen in both Madison and Louisville. However, none of the girls felt they were targeted by children's propaganda. No one recalled any books or magazines that were focused on targeting children, but rather recalled the propaganda aimed at adults.

Children also saw propaganda in newsreels shown prior to the movies at the theater. It was often through these images that the war became real to the young girls. Children were exposed to military scenes from the land, sea, and air battles. Most of the footage was shot by trained professionals, and 75 percent of the footage showed "military or naval hostilities or war-related activities."239 The Madison and Louisville girls recalled pictures of guns or howitzers being fired or even soldiers being carried out on gurneys, but of course never of soldiers actually being killed. St. Clair said that seeing those images as a young girl made her cringe. When Brennan saw the news reels at the movies, she said, "Well, it'd make you wonder sometimes is that [my brother]?" Her father would ask the same questions when the two would venture out on Saturdays to a special war news theater to try to learn more about her brothers' whereabouts.

The local newspapers and national magazines affected the girls in a similar manner. The families of the Madison girls subscribed to the Madison Courier while the families of the Louisville girls subscribed to the Courier Journal or the Louisville Times. The Courier Journal, for instance, was a much bigger paper than the Madison Courier, but as far as war news, the same types of events and information were being covered. Not all the girls read the daily paper on a regular basis but they did recall the type of news portrayed during the war. St. Clair recalled the big bold headlines while Block remembered that papers tried to inform the public about the number of dead or wounded

${ }^{239}$ Tuttle, 153. 
soldiers. She stated, "But I don't think most people realized how bad it was until a lot of them started coming home." Brennan's family always tried to keep up with her brothers through the newspapers as well, but it was hard since much of the information in the papers was late: "I don't think we heard anything until everything was over. They had all these battles and things like that, and you never knew until everything was completed." Jones recalled the pictures she would see in the magazines Look and Life. To her, the war seemed so foreign. She would see the obvious destruction in the pictures but could hardly believe it since it seemed so far away from her little town of Madison. Bear was often frightened at the truth the newspapers portrayed. It was very alarming to her as a child because she understood that at first it did not sound like the United States was doing well.

Radio was another way for the girls to receive war news as millions of American turned to the radio as their primary source of war information. ${ }^{240} \mathrm{NBC}$ and $\mathrm{CBS}$ were devoting between 20-30 percent of their air time to war news alone. Bear recalled the intensity with which her father listened to the radio even prior to Pearl Harbor. She stated,

I was young enough to remember listening to the President every time he was going to be on the radio. We were great radio listeners... But I do remember we would listen to every news broadcast that was available, and I can remember as we gathered as a farnily at least once a week with Daddy's side of the family and once a month with Mother's side of the family, that my father would sit on a chair...[and] put one hand behind one knee and cross the other knee over the other leg, and he would point his finger and he would say, 'We are going to be at war.' And that frightened me, because I really knew that war was a fight but I didn't understand any more of it.

${ }^{240}$ Lingeman, 223. 
She understood what her father was saying but never absorbed much of what the President was relaying over the radio. Many of the girls had the same reaction. Block would listen to the radio with her family at night. She recalled, "I heard a lot of Fireside Chats from my president." McCauley remembered her grandmother listening to the radio before the U.S. entered the war but especially after her uncle joined the Navy. The girls all had access to the same type of radio programs and newspapers regardless of their size of community. They were receiving the same information in the same format.

Since the young girls from Madison and Louisville were exposed to the same types of media and propaganda, it is not surprising that they shared like views of their enemies, i.e. the Germans and the Japanese. All the girls had negative feelings towards both groups, including Hitler of course, but most of the girls had a stronger dislike of the Japanese because of their attack on Pearl Harbor and the fact that the girls perceived them as culturally different. Many of the girls described the enemies as "bad people," and when asked about Hitler, St. Clair stated that I had mentioned the "H" word and Brennan recalled that at the time, he was the meanest man she had ever heard of. However, the girls found it hard to hate the Germans because several had relatives of German descent or knew of people who were German. It was much easier to despise the Japanese. McCauley explained,

My grandmother was of German descent...so it was kind of tough to be mad at the Germans, but then the Japanese were little yellow people, you know, and they were so different from us... They were terrible people to just come in on a Sunday morning and bomb people...They were bad. We hated them. As kids, we hated them, you know.

Jones's negative feelings about the Japanese stemmed from hearing of Japanese cruelty to women and children. All these years later, she remembered a particular picture that 
created that emotion. It was a picture she saw in a news reel where the Japanese had just killed a young child. She said, "I couldn't believe that anybody would do anything like that. That really impressed me."

The Louisville girls shared similar opinions on the Japanese. Block as a child obviously did not like Hitler or the Germans but knew she disliked the Japanese more. Her resentment stemmed from hearing horrible stories about how they treated the prisoners and also because of the attack on Pearl Harbor. Brennan felt that because everyone was so unprepared for the attack on Pearl Harbor, many Americans, including these young girls, felt a stronger resentment toward the Japanese. According to St. Clair, "hate" was the predominant feeling that accompanied these enemies, because the girls were little kids and did "whatever their mothers and daddies [told] them...And everything then was hate."

American children often had different ideas about where the fighting was taking place. Many lived in constant fear of being attacked, which was aided by Pearl Harbor, air raid drills, and blackouts. ${ }^{241}$ One such Indiana youngster would always listen to the war news right before she went to bed. She had no real concept of where Germany was and figured it was probably located around Ohio. She was afraid at any minute a German soldier would come into her bedroom. ${ }^{242}$ A California girl also felt that war was close to home and designed war escape plans with her sister to avoid the enemy soldiers if they ever came to their house. The sisters would sneak to a back bedroom that held a closet where their mother stored large garment bags. They believed they could hide behind the bags in the closet where no one would find them. However, if discovered, they planned

\footnotetext{
${ }^{241}$ Tuttle, 5.

${ }^{242}$ Morris.
} 
to douse themselves with ketchup they kept in the closet specifically for that reason and would pretend to have "already been bloodied and killed.",243

Again because of their similar backgrounds and views on the war, both sets of interviewees had the same thoughts on the war geographically and shared the general belief that war was far away from them. Most of the girls could at least point it out on a map but were not particularly afraid of war coming to Louisville or Madison. St. Clair knew that it "just was over a big, big thing of water." Block recalled that many local businesses had maps up so you could tell where things involving the war were going on. Jones thought she was too young to take it all in geographically. She stated, "It looked far away, so I don't remember worrying about it." McCauley figures she could have located Japan or Germany on a globe or map but did not have much of an overall concept. At school, Bear remembers teachers pointing out the various locations on a large map, but she still felt like she was not overly in tune with the location in proximity to her own life. After listening to war news on the radio, her father would even get out their atlas and place it out on the dining room table to show her the places discussed in the broadcast. She recalled, "Even at that time on a piece of paper that was foreign to me. That was way, way far away, because I thought an ocean was almost impossible to cross."244

This lack of geographic understanding of the war makes sense because many of the girls had not ventured too far out of their own counties, and certainly not out of the

\footnotetext{
${ }^{243}$ Mark Jonathan Harris, Franklin D. Mitchell, and Steven J. Schechter, The Homefront: America During World War II, with an Introduction by Studs Terkel, (New York: G.P. Putnam's Son, 1984), 69, and Studs Terkel, "The Good War": An Oral History of World War II, (New York: Ballantine Books, 1984), 232 234.

${ }^{244}$ At our interview, Bear even brought the old Atlas her father had used during WWII to show her family the locations of different war places and events.
} 
state. Several of the girls' families did not even own a car, and those who did used them scarcely for such things as visiting relatives or Sunday drives. Due to their social class, the girls generally walked everywhere or used inexpensive public transportation. For instance, McCauley's uncle had a car before he went into the Navy but he only used it on summer evenings to take her grandmother out for a ride. Brennan's father was unable to drive a car due to his heart condition, but she stated, "Very few people even had cars...We didn't have one, and I know none of my neighbors had one...I can't think of anybody who even had one!" This limited mobility created by their social status demonstrates how children who had hardly traveled out of their own state were unable to grasp the war geographically.

As this chapter exemplified, the size of the cities these young girls grew up in did not affect them differently concerning the changes World War II brought to their childhood activities, entertainment, media, and propaganda. The main reason for this is because the girls in both Louisville and Madison experienced their particular neighborhoods of their cities as a small town. This was due to their age and social status. World War II brought similar changes to both Madison and Louisville, if even on a different scale size, which in turn created the similar experiences the girls encountered. 


\section{CHAPTER 5}

\section{HOUSEHOLDS, PERSONAL LIVES, MEMORIES, AND WWII}

The communities of Madison and Louisville have thus far been shown to have been affected by World War II in the same way, which in turn has given the six girls similar experiences. The way war affected industry, childhood activities, media, and propaganda was essentially the same. Since these aspects of the young girls' lives have turned out to be the same, it should be no surprise that the changes the war forced upon their own households and personal lives and their memories concerning particular events of the war were also congruent. The size of community did not play a major role in determining wartime changes such as the removal of draft-age relatives, rationing, air raid drills, and the girls' memories of major events like Pearl Harbor, V-E day, and V-J day. These changes affected the girls in much the same manner mainly because the changes were implemented by the same outside source: the national government. The government imposed such restrictions as rationing on all of its citizens, but viewing changes like this from a child's somewhat limited perspective can demonstrate how deeply the changes affected or did not affect various communities and people.

During the war, many children's lives were altered by the absence of a father, brother, brother-in-law, cousin, uncle, or even family friend. It has been estimated that "nearly one family of every five-18.1 percent — contributed one or more family 
members to the armed forces." ${ }^{, 245}$ Around 13 million men ranging in age from 18 to 50 were drafted or enlisted for the war effort by the end of $1943 .{ }^{246}$ It would have been difficult to not know someone who was sent off to war. All six interviewees had close family members in the armed forces, although luckily most returned home and were not among the 405,399 war fatalities. ${ }^{247}$ However, when the girls' family members first left, their future was unknown, and a high level of stress and worry appeared in every household, regardless of community.

Out of the six interviewees, the households were most affected when an immediate family member was sent overseas. McCauley's uncle, who lived in her home, joined the Navy after the U.S. entered the war. He wanted to make sure he had a clean bed to sleep in at the close of each day, so he joined the Navy before he could be drafted into the army. She was saddened by her Uncle Bud's removal from her home, because she viewed him as a surrogate father and missed his presence. Her grandmother was worried the entire time he was gone. McCauley stated,

My grandmother worried so much about him and that affected both Jeanette and me. Of course, it was Jeanette's father, and Jeanette's mother had died when Jeanette was a baby, so Mom [which is what she called her grandmother] was so worried that Jeanette was gonna be left an orphan with nobody....

The worry McCauley's grandmother had for her uncle left a gloom over the house.

Although much of the concern was for the future of Jeanette if her father did not return, McCauley felt like she was affected more by this worry than Jeanette herself, since Jeanette was just 3 or 4 at the time. Luckily, her Uncle Bud did return safely home.

\footnotetext{
${ }^{245}$ Tuttle, 31.

${ }^{246}$ Lingeman, 135.

${ }^{247}$ Tuttle, 44.
} 
St. Clair and Brennan had similar experiences within their households with their older brothers being in the armed forces. Their mothers, as previously discussed, even took war jobs at the Charlestown Bag Plant to keep their minds off their sons in the service. St. Clair had a general idea why her brother was going overseas and comprehended some of the feelings her mother was going through. She said, "Course when you're that age, you don't have a real, real deep feeling if you were like Mom of course, but still you was old enough to miss your brother." She recalled her mother crying a lot during the war but said her father kept his feelings inside "just like any other tough man." Brennan's parents were very upset when they found out both their sons would be fighting in the war. Her father was a veteran of the First World War, so he had a deeper understanding of all that war entailed. Her mother was not only worried about her two sons who were overseas but also her husband who had a heart condition. She was afraid that their sons' involvement in the war would cause him to have more heart problems, and in fact he had two minor heart attacks while they were gone. Her mother was afraid to be alone while Brennan was at school and her husband was at work because she would only think about the war and her sons. She felt as if she had to take a war job to be able to focus on something else and then of course help her sons while she was at it. Jones's two older brothers were drafted for the war effort, so at first, her family had the same worries and stress as McCauley's, Block's, St. Clair's, and Brennan's. When they first left she said, "Well, you were sad because Mother and Dad were so worried as to what was ahead of them..." Luckily for the Jones's, neither of her brothers were shipped overseas. They were stationed in the United States for the entire war. After her parents discovered that they no longer had to worry about their sons' immediate 
safety, their stress was removed. Jones stated, "We were very fortunate there...There wasn't that added stress in the family that there were in many families." They became more concerned about her sister's fiancé and some other people they knew that were overseas.

Not only did stress levels rise from relatives being sent overseas but actual work. strain was placed on a couple of families. Although Jones's brothers were not sent overseas, for which the entire family was very thankful, her father lost two of his farmhands with the removal of her brothers from their home. They had previously helped her father on the family farm. When they left, Jones's mother had to work really hard filling in for them, although she did not do a lot of actual 'man's labor.' Block's stress was more serious. Although the war ended in August 1945, her brothers were not scheduled to return from overseas yet. Unfortunately, a tragic accident occurred at the brewery where her father worked off Frankfort Ave in September 1945. An explosion occurred, and her father was killed. Her older brother returned home at Christmas that year, but was anxious to return to Washington where he had worked prior to WWII. Block's mother asked the Red Cross if her younger brother could be "released from the service because she needed help financially." He made it home early in 1946.

Holidays, particularly Christmas, were somewhat subdued with close family members removed from the home. What usually was a joyful time of celebration often was clouded by the gloom of war. As Jones realistically stated, "I know the war affected everything." McCauley recalled that the radio still played Christmas music and programs, but since her uncle was gone, the holidays were changed. She knew, however, that her grandmother still did the best she could for her cousin and herself since they were 
young kids. Block felt that the holidays were quieter with her brothers gone and the family spent less, especially after her father died. St. Clair recalled her family having pity on her brother since he could not be at home to celebrate. They would say, "Poor little Haynes! Where is he today? We can't have him with us."

Some of Brennan's holiday traditions were fully altered by the war and the absence of her two brothers. Shortly after Thanksgiving every year prior to WWII, Brennan, her German grandmother, and her mother got together to make German cookies called Springleys. It was quite a process with the dough cut-outs sitting out over night on the dining room table. The next morning, Brennan's mother would wake up early and bake them. After baking the Springleys, her mother would place them in a pillow case, and they became the children's Christmas cookies, which they were not allowed to eat until the holiday. After the war started, the Springleys tradition was put on hold. Brennan stated, "Well, Mother didn't have time to make these cookies anymore until the war was over. We just didn't have time."

Another of Brennan's family traditions that was altered due to the war was Thanksgiving dinner. In 1944, her mother worked a lot of overtime, and that year she had to work on Thanksgiving Day. Brennan stated,

And I 'member, my father and I, we went down to the Blue Boar down there at $4^{\text {th }}$ and Walnut and ate our Thanksgiving meal that time. That was a change... But that one Thanksgiving, that must've been when the war was really in the heaviest part that they had to work that holiday.

Even though certain traditions fell by the wayside and the holidays were quieter without her siblings, there was one thing Brennan's mother refused to do without: a Christmas tree. She said that no matter what happened in her life she would "always have a 
Christmas tree." Brennan remembered that she and her parents put the tree up and decorated it, but it was different since not all of her family members were present.

The war did not exempt young men based on their communities, so the loss of most of the draft-age men similarly affected the families in and communities of both Madison and Louisville. Since many of the girls had siblings around the draft age, they also saw their siblings' friends and neighborhood men drafted into the army or enlisted on their own. The shortage of draft-age men was visible to the girls in each community.

Another war-time factor that did not differ due to community size was rationing. The rationing system put into place by the American government affected all of its citizens, including the little ones. Roosevelt established the Office of Price Administration (OPA) in January 1942, and "the OPA issued the first war ration books, providing coupons for sugar, then coffee, and gasoline" later the same year. ${ }^{248}$ The point rationing system was instituted in early 1943, which affected such foods as butter, cheese, fats and oils, processed foods, and meat, with shoes being added to the list later. Quotas were set by local rationing boards which allotted coupons to every family. ${ }^{249}$

Homefront children across the nation recall many of these deprivations, although often they take pride in having 'made do. ${ }^{250}$ Children remember the substitute foods their parents would concoct such as Marshmallow Ice Cream, since it used a limited amount of sugar. Items such as bubblegum became a prized possession to many young children during the course of the war, as it was placed on the ration list. Some children were even biddable to eat unusual cuts of meat such as tongue and tripe, while others

\footnotetext{
${ }^{248}$ Tuttle, 127

${ }^{249}$ Ibid.

${ }^{250}$ Ibid.
} 
were excited to receive rationed foods such as real butter as gifts during the holidays. ${ }^{251}$ Children were also aware that other items such as shoes and rubber were rationed. For instance, the old balloon tires on children's bicycles were replaced by thin ones to conserve rubber. The new faster bicycles with thin tires were thus dubbed Victory Bikes during the war. ${ }^{252}$ Regardless of the sacrifice great, small, or not at all, many children felt they simply 'made-do.'

The Madison and Louisville girls all vividly remember rationing but never felt they were truly deprived of much, whether because their families had just come out of the Depression and had not had extra items for a while or because they simply adjusted to doing without. Most of the girls' families were very much meat and potatoes type people prior to the war, which was the food trend of the time. Bear recalled that her mother often had meat and mashed potatoes, and no matter what the meat, she "could make gravy with that." The only two vegetables her mother cooked that she did not cream were green beans and carrots. Everything else Bear's mother creamed, which was also a trend at the time. The other girls described their pre-war meals also consisting of mainly meat, potatoes, and a vegetable or two, often served with some sort of dessert.

Although rationing of particular daily food iterns changed the way their mothers cooked or what they used to cook, none of the girls recalled being hungry. Many remembered substitute items their mothers used. Bear and Jones commented on the butter shortage which allowed margarine to become more popular as a product. Bear stated, "You could mix up [Oleo margarine] in your hands and make it look like butter, and then try to get it into a rectangle so it'd look like butter, which you couldn't do."

\footnotetext{
${ }^{251}$ Tuttle, 128.

${ }^{252}$ Morris.
} 
Jones remembered that the margarine used during the war was white, but it would include a little yellow capsule with it to color the margarine, so it would look more like real butter. "You would put [the capsule] in the bowl and I remember smashing that little yellow capsule... and then that would make it look like butter...But for a little kid, that was sort of fun. You found that and you squished it..." Block recalled the ease with which her grandmother and mother could substitute rationed items during the war. They knew that they had to have ration stamps for whatever they planned on cooking or they would have to change their menu. Block stated, "My grandmother was very good about it. She could substitute a lot of things. So could my mother."

Because items such as canned goods were rationed, many Americans grew Victory Gardens to be able to provide their own fruits and vegetables. During the war, 40 percent of all the vegetables in the nation were grown in over 20 million Victory Gardens. These gardens ranged in size to hundreds of acres in farmland to small backyard plots of families living in urban cities. ${ }^{253}$ Often young children helped out with the Victory Gardens at school or at home. For instance, school children in Tampa, Florida, planted and harvested a large garden consisting of carrots, beets, lettuce, cabbage, turnips, and other vegetables to serve their schoolmates in the lunchroom during the school day. ${ }^{254}$ Other children would venture out into their backyards or designated garden plots with their families on the weekends. Due to seed shortages, some young children were even introduced to unfamiliar and different vegetables such as kohlrabi and Swiss chard. ${ }^{255}$

\footnotetext{
${ }^{253}$ Lingeman, 251.

254 Tuttle, 127.

${ }^{255}$ Lingeman, 251.
} 
Several of the Louisville and Madison girls grew Victory Gardens during the wartime to supplement their food sources. Of course, Jones, who already lived on a farm, grew many of their own vegetables and had meat products available, but Bear's family started a Victory Garden for the war effort. Bear's mother started the garden and grew items such as tomatoes, carrots, and green beans, which she then canned. Brennan's family did the same, but they also grew lima beans, radishes, and green peppers on top of the other vegetables.

Food products were not the only rationed items in short supply. A few of the girls remembered the silk, nylon, and rubber shortages, which affected women's hosiery and underclothes. Prior to the U.S. entrance into WWII, Bear recalled hearing about the war between China and Japan because it was creating a silk shortage. Women were wearing silk stockings but since parachutes were made of silk and were needed for the war effort, women here were having problems obtaining stockings. However, Bear did not fully understand the correlation between the two. She stated, "If for some reason or other, those countries fighting made my mother and grandmother have a hard time buying those nylon stockings, and I really didn't grasp why." For Brennan's eighth grade graduation in 1945, she received her first pair of nylon hose even though they were rationed and hard to get. She treated them like gold and was so scared she would get a hole in them because she did not think she would be able to get another pair.

St. Clair and other American children had bigger clothing problems due to the rubber and elastic shortage. St. Clair had little "step-ins," which were like shorts but instead of being held up by an elastic waistband, the shorts were equipped with little ties that kept them up. St. Clair recalled, “[That] wasn't good at all, because anything silky 
like that would work until it came undone. I had to know all these restrooms along the way so I could run and tie them up again going towards Broadway and $4^{\text {th }}$." Other homefront children recall the mortification a loose pair of undershorts would cause when "their underpants fell down."256 St. Clair at least had her route mapped out!

All the Madison and Louisville girls recalled the ration stamps and books their parents and grandparents were forced to use during the war and the difficulty they had with obtaining certain items, particularly those like sugar and coffee. Jones remembered the substitute items they used so they could continue making homemade ice cream during the war years: pineapple and grape nuts. They also remembered the non-food items that were rationed such as rubber and metal which affected such items as their bicycles. However, none of the girls felt that they were deprived of anything during these years. Bear recalled the shortages of food and certain physical products but stated, "We didn't suffer from this." McCauley shared the same feelings: "As a child, I know we had to have our ration tickets for whatever we bought, but I don't remember ever doing without anything."

St. Clair offered a reason that many historians agree with for why the girls were not particularly affected by rationing in a negative way. She mentioned that since everything had been in short supply due to the Great Depression and they were used to not having much money because of their social class, the girls were not really deprived of anything during the war years that they had not lacked before WWII. Rationing and the shortage of certain items due to WWII was merely a continuation of the Great Depression, which had caused more serious shortages among low-income families. Families in the working and middle class had been dealing with these and similar issues

${ }^{256}$ Tuttle, 128. 
for a decade now. The girls and their families in this study were simply used to "makingdo.'

Yet another way the war brought changes to the girls' communities during the war was through air-raid drills and blackouts. The Louisville girls recalled the air-raid drills at home and at school while the Madison girls mentioned the drills at home but not particularly at school. They may have had them at their schools, but none of the interviewees mentioned the school drills. Both communities, regardless of size, divided the cities and neighborhoods into various districts under the supervision of local air raid wardens, who were responsible for monitoring the areas during the drills.

In Madison, McCauley and Bear, who both resided in the West End of town, recollected that the blackout and air raid drills were done at the same time. During the blackouts, their radios and lights had to be turned off along with their blinds pulled. Bear said that they did not have to purchase new blinds for the drills because "in those days...blinds were made of fairly heavy material anyways to block out the sun." During the drills, the sirens would sound, the residents would pull down all their blinds, turn off their lights, and then observe the drill until the "all-clear" signal was given.

The same type of drills would occur in Louisville during the war. Brennan recalled their local air raid warden, Mr. Chandler, telling her father that he was not allowed to play the radio during the drills. The light from Brennan's radio would shine outside their door, which is what the warden was trying to curb alongside the noise. Block remembered that their blinds had to be pulled so no light was showing anywhere. Like Bear, Block said they did not have to purchase new blinds since they already had some on the windows anyhow. She stated, "'Course lot of us went out and just sit close 
to the porch or something. We weren't supposed to be there, but that's where we were. And they were very strict about the least little bit of light."

As for the school air raid drills, they were managed differently from the night ones conducted at home. Brennan and her classmates were familiar with fire drills but the air raid drills were "something different." St. Clair described them as "weird sounding, scary sounding." At Block's and Brennan's Catholic schools, the girls were taken to certain designated areas of the school or property. When Brennan was at St. Benedict's School, the students received permission to enter the church located in the basement without wearing their hats. It was a requirement in the Catholic Church at that time for all ladies and girls entering the sanctuary to be wearing hats. She said, "We had special permission to go [without our hats] when we had these air raid drills...So, when we had an air raid drill, we had to go to the basement." The drills were conducted to warn people what to do if the United States mainland was ever bombed. At Brennan's school, her teachers would tell their pupils, "We have to have these air raid drills in case we are attacked, you know like we were at Pearl Harbor." She recalled the confusion of wondering whether the drills were simply practice or the real thing. She stated, "You never did know. And they kept on-we had to have them." Air raid drills and blackouts, in some ways, brought the reality of war closer to horne, since many young children previously viewed the war as a far away anomaly.

One last aspect of the changes war brought to the communities and lives of these six young girls to be covered in this study is the effects the war had on their memories concerning major war events: Pearl Harbor, V-E Day, and V-J Day. Did the size of community the girls lived in affect, distort, or enhance their memories of the beginning 
and ending of the war? Again, the answer is no since the girls shared the similar atmosphere of a small town within their own neighborhoods. Most of the girls heard about the bombing of Pearl Harbor in a similar manner, and most stated that Pearl Harbor sticks out more in their memory than does the end of the war. However, the girls who were unable to recall V-J day were not unable to do so because of the city or neighborhood they lived in. Rather, it was just that Pearl Harbor struck them as more of a defining moment than the end of the war in their young childhood memories. This could be because Pearl Harbor was such a shock to them at a young age or because the girls were older at the end of the war and understood that the United States would soon win the war. Thus, the announcement of V-E or V-J day was not such a defining moment. Regardless, the size and location of their communities was not a determining factor.

All three of the Madison girls heard the news of the bombing of Pearl Harbor on the radio or through a family member that said to turn on the radio. Bear and her family were on a Sunday drive to Dupont, Indiana, which is located a few miles northeast of Madison, to visit one of Bear's mother's sisters when they heard the news on the car radio. Bear recalled, "We just turned around and came back down the hill and went into the house and turned the radio on...[After that] I don't remember anybody coming in. I don't remember any phone calls. It was just the family listening to as much news as we could get or on the radio." McCauley and Jones's stories were similar. McCauley said that she and her cousin were around the house playing and thought that someone told her grandmother to turn on the radio. She remembered being shocked and wondering how anyone could do that. Jones stated that she was at home on that fateful Sunday sitting on 
the couch when her brothers burst in and said that the U.S. was at war. They had taken the car into Madison and heard the news on the car radio. Jones remembered not understanding what all war meant or "what it [was] going to entail." The attack on Pearl Harbor from the girls' perspective was a frightening and shocking occurrence. They were aware of the impending talk of war, although they were unsure exactly what it meant.

The Louisville girls had similar experiences with first hearing the news. Brennan and St. Clair heard about Pearl Harbor over the radio. Brennan was at home that Sunday afternoon and was working on her homework. The news came in over the radio, and she said, "I remember how upset my father got then. I knew he was really upset. And I think what he was most concerned about [was] he knew right away what my brothers were gonna have to go through, and they was so young. I think he realized it." Block heard about the bombing on her way home from children's church. She recalled,

We had a mass at 9 o'clock on Sunday mornings for the children, and on the way home, we kept hearing all these people talking about Pearl Harbor, Pearl Harbor. 'Course none of us knew it because we were all you know... When you'd get a bunch together to walk back and forth, it was usually around the same age group as everybody, so by the time we got home, they were on the radio about it, and they had Extras out, papers out.

Despite the similar ways they heard about Pearl Harbor and their initial feelings on being attacked, not all the girls remembered V-E Day or V-J Day, which did not stick out in their minds like Pearl Harbor did. The girls who did remember the end of the war were not all from Madison or Louisville, but were instead a mix of both communities. No patterns emerged concerning age, memory, or size of location in regard to their recollections of the end of the war. Although many did not recall the actual day the war ended, most did recall the feelings that accompanied the closure of WWII. For instance, 
Block and Jones did not recall the actual V-J day, but Jones did remember that everyone was incredibly joyous when they heard. She felt like Pearl Harbor left more of a lasting impression on her mind, however. She stated, "It's funny the little things you can remember when you are a little kid." Brennan, like Jones, felt that Pearl Harbor stuck out more in her memory but she remembered that there was a lot of celebration going on in downtown Louisville when the war ended.

The other girls had very vivid memories of V-E Day and V-J Day. St. Clair remembered going to the celebration in downtown Louisville that Brennan mentioned when the war was officially over:

Everybody gathered up there at $4^{\text {th }}$ and Broadway and people [were] throwing their hats in the air and confetti and all that kind of stuff, but I don't know what they made their confetti out of but probably took something and tore it up and just threw it in the air...They was declaring the war was over, and I know everybody was tickled to death. Everybody was grabbing each other and kissing each other and everything. And I was still too little for that... They didn't want to kiss me!

For St. Clair, V-J Day stuck out in her mind just as much as Pearl Harbor did.

Bear and McCauley remembered the celebration in Madison in much the same manner. For V-E Day, Bear was downtown with a cousin that was the same age. She said,

I don't remember where exactly we were but I know we hopped on the back of a trailer-truck thinking we were going to ride around town and as it left the city limits headed [west] toward Clifty Falls State Park, we both knew we would be in trouble if we did that, so we jumped off at the entrance of Clifty Falls State Park, and we walked back to town hoping that as we walked by my home and his home that neither one of the mothers would see us.

Bear was at home for the V-J Day news but remembered "the celebration, [and] the thought that it was over and...that everybody was going to come home at once." Bear 
had a sense that the war in Europe was ending but stated, "I did not have a sense that it was ending in Japan for some reason. I was afraid that was going to go on and on and on." McCauley could not recollect V-E day at all unlike Bear, but did remember parts of V-J day. She stated,

They threw the Ohio Theater open. It was a free movie. I don't even remember what the movie was and Mother and Mom and Jeanette, and I all walked up there and went to the movie, and everybody was talking to everybody in the street and everything was happy and all, and we walked home afterwards... Of course that was the end of all the wars.

Both the Madison and Louisville girls had very similar experiences with hearing the news of Pearl Harbor, V-E Day, and V-J Day despite their varying sizes of communities. Not all the girls remembered the end of the war as clearly as the bombing of Pearl Harbor, but this has nothing to do with location. Rather, the impact and significance of the shock of being attacked probably branded their young minds more sharply than the end of the war, which some could tell was coming. This section has demonstrated that the changes the war forced upon these young girls and their families were similar concerning the removal of draft-age men from their households, rationing, air raid drills, and memories. Age and status more likely provided the girls with their similar experiences rather than size of community. 


\section{CHAPTER VI}

\section{CONCLUSION}

In this case study of young girls growing up in Louisville, Kentucky, and Madison, Indiana, during World War II, I investigated whether the differing sizes of the two communities affected the changes the war brought to the lives of the girls. The factors examined, including industry, childhood activities, propaganda, media, household changes, personal lives, and memories, all showed that the size of community did not make a difference in determining the wartime changes. Instead, the evidence shows that World War II affected the girls' lives in a similar manner because of their age and social status. Specifically, the girls' age and status in the middle to working classes limited their mobility and activities during the war. These restrictions, although not particularly negative, allowed the girls in both Louisville and Madison to view their personal neighborhoods as a small-town community.

Given the similarity in wartime experiences, what generalizations can be made about the impact of the war on their childhood? Some American children felt that WWII robbed them of their youth and forced them into adulthood too soon. Mary Morris of Connersville, Indiana, felt that the war affected her childhood negatively during it because it caused so much worry for her and stress on her parents. It also instilled prejudice in her as a young girl that was hard to get over. However, as the years went by, WWII taught her some life lessons. It helped her to appreciate what she had then and has 
now, unlike many adults and children nowadays who are spoiled, she believes, because they have never had to do without. ${ }^{257}$ Steven Mintz, author of Huck's Raft: A History of American Childhood, stated that America's WWII children "remembered the war as an elevating time - demanding and stressful, but also inspiring - a period of privation and sacrifice, but also of high ideals and purpose, when the United States and all Americans stood proud. ${ }^{, 258}$ Children's participation in the war effort also gave them a sense of "self-worth, autonomy, and initiative" that many took with them into the post-war era. ${ }^{259}$ Unfortunately, another wartime legacy for the children was the recognition of the sorrows that life and particularly war can bring. ${ }^{260}$

From interviewing the six women and becoming acquainted with their views on WWII, I imagine that many would agree with Mintz's statements about the war. However, when asked if they thought the war changed them personally or if they missed out on their childhood, the girls shared the belief that the war did not radically inhibit their youth. McCauley did not think the war affected her childhood either positively or negatively. She said, "We just went through it. I think our parents, all of my friends' parents...all of them worked very hard to keep our childhood as innocent as possible and as normal as possible." Jones felt that since she was so young, she did not remember ever being without something and never really suffered. She recalled the patriotism of the times and the outlook that people shared concerning the war. Bear stated, "I would have to view it as just a thing of history that came about and hopefully some good came out of it...I don't really think it affected me. I don't think I really changed at all. Maybe

\footnotetext{
${ }^{257}$ Morris.

${ }^{258}$ Mintz, 274.

${ }^{259} \mathrm{Ibid}$.

${ }^{260}$ Ibid.
} 
in the city I would have seen more soldiers or things like that but we were sort of protected." Unbeknownst to Bear, the Louisville girls had similar experiences, and felt the same way as the Madison girls did. Block did not believe the war affected her childhood in either a positive or negative manner. She said,

It's just something you live. You only remember what you want to...There wouldn't have been all this camaraderie that there was with the kids collecting all this stuff and all. That part of it was very good, but I didn't like to hear about all the killings and the stuff that went on... There wasn't much I could do about it. A lot of times, I'd just try to forget.

St. Clair did not think the war affected her childhood negatively but believed that if the war had not occurred that many people would have had "more of a peaceful feeling all [their lives] without the war hanging over [their] heads." Brennan also agreed that the war did not cause her to miss out on a childhood because she was still able to do other things but she did point out it added extra responsibility to her life. She stated,

You know everybody had to pitch in and do something to help...I was a little concerned always about my father with him having his heart condition. It did bother me...In addition, you never knew for sure if my brothers would come out alive or not. That's something nobody knows, but we were very fortunate that they did. I think it makes you think a lot about things. You know, when you're young like that [you] just think things go on forever. You don't never think anybody's ever going to pass away or won't never be here...That just never enters your mind.

So despite many of their family members taking war jobs or fighting in the war, despite many food products being unavailable, and despite the disruption of their childhood activities, these six women do not believe their childhoods were negatively affected by the war. Instead, they took things in stride and 'made-do' with their situations and what they were given. Most of the women believed the war was necessary since the United States had been attacked, but of course wanted it to be over as soon as possible. McCauley stated, "We were certainly glad when it was over. We were glad 
when the boys all came home. [However], we thought it was a war that needed to be fought." Since the war was a necessity, the girls, even at a young age, also did what they thought or were told was necessary.

It is clear that the size of the communities in which they lived did not play a major difference in these young girls' lives, but age and social class were the prominent determining factors. Since the girls were categorized into a relatively narrow age cohort and shared membership in the working to middle class group, their experiences were often viewed from the perspective of young girls immersed in a small town atmosphere. The girls in both communities did not travel frequently out of their neighborhood spheres because they were too young and did not have the financial means to do so. Their daily lives, and thus their general perspectives, were wrapped up in the small community atmosphere contrary to the actual size of their overall location.

The six oral history interviews provided the base for this case-study, and even though the interviews were historically beneficial, the standard problems with oral history occurred to some measure. The number of girls interviewed, the subjectivity of the questions asked, or the unbiased memories of the interviewees are usually questioned by researchers who do not completely validate the oral history methodology. These oral history skeptics raise some valid points with their objections, but I believe than any historical document or resource can potentially have similar faults or weaknesses as an oral history interview. However, there were certain instances within the course of my interviews where the women had trouble remembering certain facts, confused certain events with others, and even blatantly contradicted themselves. But any good historian should support his/her main sources, whether they be oral history or not, with other 
contingent sources. The use of oral history for this type of study is crucial, despite its weaknesses, because it "reveals daily life at home and at work - the very stuff that rarely gets into any kind of public record...It is through oral history that the dimensions of life within a community are illuminated."261 This is particularly important because children rarely leave behind written or public records and their view on life within a community is very different than that of adults.

There are not enough studies done on large and small cities to determine if Madison and Louisville experienced typical nationwide wartime experiences, although I believe they probably did since many of their experiences coincide with those listed by such authors as Tuttle, Mintz, and Kirk. I agree with other historians that location can be a major factor if the distance and demographics of those locations are different, but size of location also needs to be a determining factor. I conclude based on my research and evidence that these girls had pretty typical experiences within the realms of this case study, but cannot be sure they had typical ones nationally without more evidence with which to compare. I hope that, with the passing of time, more comparisons between children in certain locations and studies done on specific towns and regions of varying sizes will be accomplished to fill in the gap in literature concerning these topics in the WWII era.

Children during wartime, whether the Revolutionary War, the Civil War, or WWII, often share very similar experiences simply because they are children. Marten's book Children in War demonstrates how war affects children in similar ways across time and space. At the same time, Tuttle brings up important factors, at least in WWII, that can affect these universal experiences such as age, culture, class, and tradition. This

${ }^{261}$ Yow, 12. 
thesis takes a more narrow focus than the other two, but it validates both approaches to some extent. If certain factors such as age and class are aligned, children, regardless of size of location, can have a similar experience, which demonstrates that war can affect children in similar ways while at the same time other factors can bar a true universal wartime experience. 


\section{REFERENCES}

1). Primary Sources

A. Interviews

Bear, Mary Jane Sauley. Interview by author, 28 Aug. 2006, Madison, Indiana. Tape recording. The Oral History Collection, University of Louisville, Louisville, Kentucky.

Block, Rosemary Woods. Interview by author, 12 Feb. 2007, Louisville, Kentucky. Tape recording. The Oral History Collection, University of Louisville, Louisville, Kentucky.

Brennan, Marian. Interview by author, 5 Feb. 2007, Louisville, Kentucky. Tape recording. The Oral History Collection, University of Louisville, Louisville, Kentucky.

Jones, Nancy Jessup. Interview by author, 6 Nov. 2006, Madison, Indiana. Tape recording. The Oral History Collection, University of Louisville, Louisville, Kentucky.

McCauley, Caroline Lynch. Interview by author, 4 Dec. 2006, Madison, Indiana. Tape recording. The Oral History Collection, University of Louisville, Louisville, Kentucky.

Moon, June McCormack. Interview with Eliza Davino and Sandra Stewart Holyoak, 20 Oct. 2003. Transcripts. New Brunswick History Department, Rutgers Oral History Archives.

Morris, Mary May. Interview by author, 9 April 2006, Morristown, Indiana. Tape recording. The Oral History Collection, University of Louisville, Louisville, Kentucky.

St. Clair, Ann Farris. Interview by author, 28 Feb. 2007, Louisville, Kentucky. Tape recording. The Oral History Collection, University of Louisville, Louisville, Kentucky. 
B. Newspaper Sources

The Courier Journal, Microfilm Collection, Ekstrom Library, University of Louisville, Louisville, Kentucky.

11 May 1941.

12 Dec. 1941. "Volunteer Workers of All Classes Answer Call,"

8 Dec. 1941. "Kentucky Is Ready to Sacrifice To Meet Attack, Johnson Says,"

25 Jan. 1942. "You Can Find Your Niche in This List of Jobs!"

22 Feb. 1942. Alleen Christen, "Girl Scouts Are All-Out For Defense."

27 March 1942. "40,000 Schoolchildren Make Articles for Soldiers."

5 May 1942. Tarleton Collier, "Social Workers Plan to Curb Delinquency."

4 Nov. 1942. "What Women Can Do: Red Cross Calls for Helpers To Make Surgical Dressings."

6 May 1943. "Nutritionist Addresses Victory Club."

13 May 1943. "Children, Too, Have Place in War Effort."

29 May 1943. "10 Ahrens Pupils Are Winners in Poster Contest."

15 March 1944. Marion Porter, “"Where Are WE Supposed to Go."

23 April 1944. Edna Carroll, "Work on Farm Prescribed To Solve Juvenile Problem.”

30 April 1944. "Something for the Boys with Bars."

9 June 1944. "Rotary Club Meeting Opens Bond Drive."

18 Sept. 1944. "Junior Red Cross Girls 'Out for Blood.””

1 Oct. 1944. "Red Cross, Far Under Quota of Dressings, Asks Volunteers." 
"Red Cross Speaker to Tell How to Write to Prisoners."

19 Nov. 1944. "Junior Red Cross Does a Lot," The Courier Journal Rotary.

11 April 1945. "Women's Action Group for Peace Organized."

The Madison Courier, Microfilm Collection, Madison-Jefferson County Public Library Archives, Madison, Indiana.

11 Aug. 1939- 2 Dec. 1939. Miicrofilm Reel 207.

23 Aug. 1939. "Americans Are Called Home."

10 Dec. 1940. "Madison Project Gets Formal O.K.: Proving Ground Land Purchase to Start at Once-500 Families to Move."

21 March 1941. Edith Chaplin, "Marble Corner: A Lament."

27 March 1941. "JPG Dwellers Vacate.”

19 April 1941. "Only Seven Families Remain in JPG Tract."

12 Dec. 1941. "Local Plants Turning Out Defense Products."

Advertisement from the International Business Machines Corporation.

Meese, Inc. Advertisement.

3 June 1942. "Plan Benefit Party."

"Foreign Newsrnan to Speak Before Rotary." "Scouts Collect Rubber."

10 Aug. 1942. "Many Names Missing: Rotary War Service Group Appeals for Help."

18 Aug. 1942. "Sew for Red Cross."

"Take Up First Aid." 
19 Aug. 1942. "USO Organized."

5 Jan. 1944. "Prayer Meeting at 7:30."

6 Jan. 1944. "Will Not Collect Fats."

7 Jan. 1944. "Kiwanis Lists Aims,"

"Report Red Cross Work."

13 Jan. 1944. "To Honor Soldiers."

17 Jan. 1944. "Will Keep Clippings."

21 Jan. 1944. "To Dedicate Flag."

13 Aug. 1945. "Construction at JPG Halted: About 300 Outside Laborers Affected by Government Order."

14 Aug. 1945. "JPG Prepares to Limit Operation: War

Department Instructions Say Reduce to Peacetime Basis When Japs Quit."

18 Aug. 1945. "Cutbacks Bring Work Stoppages: Meese, Inc. Releases 200 and Meyers 75 After Cancellations."

1954. "Meese, Inc.: In Retrospect."

28 Jan. 1989. Steve White, "Quality Cited by Meyers' Worker."

Memo About Meyers and Son Manufacturing Company.

C. Other

Andriot, Donna, ed. Population Abstract of the United States, 1999 ed. Farmington Hill, MI: The Gale Group, 2000.

Andriot, John L., ed., Population Abstract of the United States. McLean, VA: Andriot Associaties, 1983.

Baruch, Dorothy W. You, Your Children, and War. New York: D. Appleton-Century Company, Inc., 1942. 
Hoffman 's City Directory of Madison, Indiana. Quincy, IL: The Hoffman Directories, 1939, 1942, and 1947.

Johnson, Betty. "Madison: Typical American Town," The Courier Journal Roto-Magazine. 27 June 1943, Madison-Jefferson County Public Library Archives.

Kast, George Henry. "History of Jefferson Proving Ground from December 30, 1940-December 31, 1942." Vol. I. January 1943, Madison-Jefferson County Public Library Archives.

Madison 1936-1938, Preserved by Harold Lohrig, in Madison in the Movies, Presented by The Cornerstone Society, 2006.

Reed, Paul W. "History of the Jefferson Proving Ground From 1 July 1945 to 30 September 1945." Vol. XII, November 1945. MadisonJefferson County Public Library Archives.

Roosevelt, Franklin Delano. "Annual Message to Congress: The 'Four Freedoms' Speech." 6 January 1941, www.fdrlibrary.marist.edu/4free.html, 14 November 2006.

Terkel, Studs. "The Good War": An Oral History of World War II. New York: Ballantine Books, 1984.

The Town. Produced by the United States Office of War Information, 1945, in Madison in the Movies. Presented by The Cornerstone Society, 2006.

2). Secondary Sources

Baker, Sue. Echoes of Jefferson Proving Ground: For Defense of Our Country. Indianapolis: Guild Literary Services, 1990.

Greene, Bob. Once Upon a Town: The Miracle of the North Platte Canteen. New York: Harper Collins Publishers, Inc., 2002.

Harmon, Shirley. "A Comparison Study of Black and White Women War Workers in Louisville, Kentucky During World War II." M.A. Thesis, University of Louisville, 1999.

Harris, Mark Jonathan, Franklin D. Mitchell, and Steven J. Schechter. The Homefront: America During World War II. with an Introduction by Studs Terkel. New York: G.P. Putnam's Son, 1984. 
Harrison, Lowell H., and James C. Klotter. A New History of Kentucky.

Lexington, KY: The University Press of Kentucky, 1997.

Hoffman, Alice M. and Howard S. Hoffman. "Memory Theory: Personal and Social." In Handbook of Oral History, ed. Thomas L. Charlton, Lois E. Meyers, and Rebecca Sharpless, 275-296. Lanham, MD: AltaMira Press, 2006.

Jefferson Proving Ground Golden Anniversary Booklet, 10 May 1991.

Kirk, Robert William. Earning Their Stripes: The Mobilization of American Children in the Second World War. New York: Peter Lang, 1994.

Kleber, John E., ed. The Encyclopedia of Louisville. Lexington, KY: The University Press of Kentucky, 2001.

Lindenmeyer, Kriste. The Greatest Generation Grows Up: American Childhood in the 1930s. Chicago: Ivan R. Dee, 2005.

Lingeman, Richard. Don't You Know There's a War On?: The American Home Front, 1941-1945. New York: Thunder's Mouth Press, 2003.

Marten, James, ed. Children and War: A Historical Anthology. With a Foreword by Robert Coles. New York: New York University Press, 2002.

Mintz, Steven. Huck's Raft: A History of American Childhood.

Cambridge, MA: The Belknap Press of Harvard University Press, 2004.

Newton, Wesley Phillips. Montgomery in the Good War: Portrait of a Southern City, 1939-1946. With an Introduction by Allen Cronenberg. Tuscaloosa, AL: The University of Alabama Press, 2000.

Press Release from Paul Entin, Media Relations for Meese Orbitron Dunne Company, 20 November 2006.

Smith, Bruce C. The War Comes to Plum St.. Bloomington: Indiana University Press, 2005.

Spinney, Robert G. World War II in Nashville: Transformation of the Homefront. Knoxville: The University of Tennessee Press, 1998.

Tuttle, Jr., William M. "Daddy's Gone to War: The Second World War in the Lives of America's Children. New York: Oxford University Press, 1993.

Williams, Elizabeth McKee. "Childhood, Memory, and the American 
Revolution." In Children and War: A Historical Anthology, ed. James Marten, With a Foreword by Robert Coles. New York: New York University Press, 2002.

Yater, George H. Two Hundred Years at the Falls of the Ohio: A History of

Louisville and Jefferson County. Louisville: The Heritage Corporations, 1979.

Yow, Valerie Raleigh. Recording Oral History: A Guide for the Humanities and Social Sciences, $2^{\text {nd }}$ ed. Walnut Creek, CA: AltaMira Press, 2005.

www.meeseinc.com/about/shtml, "About Us,"15 November 2006. 


\section{CURRICULUM VITAE}

NAME: Michella Mary Marino

University of Louisville, M.A. in History, May 2007

Hanover College, B.A. in History, May 2004

ADDRESS: Department of History

101 Gottschalk Hall

University of Louisville

Louisville, KY 40292

D.O.B.: Janesville, WI - March 1, 1982

EDUCATION

\& TRAINING: $\quad$ B.A., History

Hanover College

2000-2004

M.A., History

University of Louisville

2005-2007

Graduate Teaching Assistantship, 2006-2007

Graduate Office Assistantship, 2005-2006

Researcher/Author of Independent History Department Project, Summer 2006

History Department Liaison for Curriculum Education Project, Fall 2005

AWARDS

\& HONORS: Member of Phi Alpha Theta History Honor Society

Carl G. Ryant Oral History Scholarship Award Recipient

Senior Graduation Speaker, Hanover College Graduation, May 2004

Editor-in-Chief, Hanover Historical Review

Phi Mu Scholarship Chair

Moderated Multi-Media Project Session at 2006 Annual Oral History Association Conference 